\title{
Local labor market effects of public employment ${ }^{* \dagger}$
}

\author{
Jordi Jofre-Monseny ${ }^{1}$, José I. Silva ${ }^{2}$, and Javier Vázquez-Grenno ${ }^{1}$ \\ ${ }^{1}$ Universitat de Barcelona and Institut d'Economia de Barcelona \\ ${ }^{2}$ Universitat de Girona
}

November 29, 2018

\begin{abstract}
This paper quantifies the impact of public employment on local labor markets in the long-run. We adopt two quantitative approaches and apply them to the case of Spanish cities. In the first, we develop a 3-sector (public, tradable and non-tradable) search and matching model embedded within a spatial equilibrium model. We characterize the steady state of the model, which we calibrate to match the labor market characteristics of the average Spanish city. The model is then used to simulate the local labor market effects of expanding public sector employment. In the second empirical approach, we use regression analysis to estimate the effects of public sector job expansions on decadal changes (1980-1990 and 1990-2001) in the employment and population of Spanish cities. This analysis exploits the dramatic expansion of public employment that followed the advent of democracy in the period 1980 to 2001. The instrumental variables' approach that we adopt uses the capital status of cities to instrument for changes in public sector employment. The two empirical approaches indicate that public sector jobs crowd-in private employment. This job increase concentrates in the non-tradable sector as the higher local wage bill increases local demand for the non-tradable good. However, these new jobs do not translate into a substantial reduction in the local unemployment rate as better labor market conditions increase the city's labor force due to migration.
\end{abstract}

JEL Classifications: J45, J64, H70, R12.

Keywords: public employment, search, local multipliers, unemployment.

\footnotetext{
${ }^{*}$ We are grateful to the editor, two anonymous referees, Giulia Faggio, Max von Ehrlich, Joan Monras, Pedro Gomes and Manuel Toledo as well as seminar and conference participants for valuable comments. We ackowledge funding from Ministerio de Economï $i^{1 / 2 a}$ y Competitividad -ECO2016-75941R (Jofre-Monseny and Vi $i^{1 / 2 z q u e z-}$ Grenno) and ECO2017-82350R (Silva)-, Generalitat de Catalunya -2017SGR796 (Jofre-Monseny and Vi $i^{1 / 2 z q u e z-}$ Grenno) and 2017SGR0558 (Silva).

${ }^{\dagger}$ Jordi Jofre-Monseny, Av. Diagonal 690, 08034 Barcelona, email:jordi.jofre@ub.edu, Tel.: (+34) 934039079 ; José I. Silva, Campus de Montilivi, 17071 Girona, email:jose.silva@udg.edu, Tel.: (+34) 972418779; Javier Vázquez-Grenno, Av. Diagonal 690, 08034 Barcelona, email:jvazquezgrenno@ub.edu, Tel.: (+34) 934039934.
} 


\section{Introduction}

Public employment constitutes a significant fraction of employment. In 2013, the share of public employment in total employment was, on average, $21.3 \%$ in OECD countries ${ }^{1}$. Hence, policies regarding public sector wages and employment are likely to influence the labor market. The objective of this study is to estimate the long-run labor market effects of public employment at the city-level.

There is evidence from different countries indicating that governments use public employment as a policy tool to affect local labor market performance. Specifically, governments use the distribution of public employment within their countries' geography as a means to reduce spatial differences in unemployment. In 1992, up to 400,000 jobs in public works in East Germany cushioned the rise in unemployment that followed re-unification (Kraus et al., 1998). In Spain, jobs in public works have been created in rural and lagging areas as a means to increase local disposable income (Jofre-Monseny, 2014). In Sweden, the creation of universities in less prosperous cities has formed part of the country's regional policy to reduce regional economic disparities (Andersson, 2005). Public sector workers have been relocated in the UK. Among other objectives, these policies aimed at stimulating economic activity in less prosperous areas (Faggio and Overman, 2014). Less explicitly, interregional income redistribution has partly been achieved through a higher concentration of public sector jobs in the south, both in Italy (Alesina et al., 2001) and in Spain (Marqués-Sevillano and Rosselló-Villallonga, 2004). Focusing on risk sharing between Norwegian regions, Borge and Matsen (2004) show that public employment is a prominent force for counterbalancing local economic shocks.

Increasing the number of public employees in a city increases the demand for local services such as housing, restaurants and hair-dressers, crowding-in private employment. However, this effect may be offset by increases in local wages and prices that might follow the public employment expansion. This crowding-out effect can be particularly acute in the tradable sector since local workers do not significantly affect the demand for locally produced manufactures. In addition, local job creation can increase in-migration rates, which might also weaken the link between more jobs in the local economy and a lower unemployment rate among its residents.

To quantify the long-run local labor market effects of public employment, we adopt two quantitative approaches that we apply to the case of Spanish cities. In the first, we calibrate and simulate a search and matching model with geographically mobile workers. In the second, we resort to regression analysis. The two analyses indicate that public employment crowds-in private employment. This employment increase concentrates in the non-tradable sector as the higher local wage bill increases local demand for the non-tradable good. However, this increase in local jobs does not translate into a lower unemployment rate as the local workforce increases due to migration.

\footnotetext{
${ }^{1}$ OECD (2015).
} 
We develop a search and matching model $\ddot{i}^{1}{ }^{1 / 2}$ la Pissarides (2000) and embed it in a spatial equilibrium framework. There are 3 sectors in the economy (public, tradable and non-tradable). Homogeneous workers only search for jobs when are unemployed and job creation takes place when a firm and a worker meet. Unemployed workers can move at zero cost and it is assumed that each city is sufficiently small, implying a fixed reservation utility for the unemployed. Workers consume all their income on a tradable good, a non-tradable good and land. The latter two prices are endogenous and clear their respective markets while the price of the tradable good is exogenous and determined in the national (or international) market. Vacancies and wages in the public sector are exogenously determined while, in the private sector (tradable and nontradable), free-entry means that firms open up vacancies until the expected value becomes zero.

We characterize the steady state of the model, which we then calibrate to match the labor market characteristics of the average Spanish city. Then, we use the model to simulate the local labor market effects of expanding public sector employment. Public sector jobs attract people to the city which increases the local cost of living. As a result, wages in the private sector rise as the higher cost of living is internalized in the wage bargaining process. In the non-tradable sector, the wage increase is offset by the rise in local demand for the non-tradable good whose price increases and boosts employment in this sector. In contrast, the demand for the locally produced tradable good remains unaffected and tradable employment is reduced. In our baseline calibration, one additional public sector job creates 0.8 jobs in the non-tradable sector and destroys 0.4 jobs in the tradable sector. The resulting increase in the workforce amounts to 1.6 individuals. As a result, large expansions in public employment have only modest impacts on the local unemployment rate. Increasing public employment by $50 \%$ reduces unemployment by only 0.4 percentage points.

In the second empirical approach, we use regression analysis to estimate the effects of public sector job expansions on decadal changes (1980-1990 and 1990-2001) in the employment and population of Spanish cities. This analysis exploits the dramatic increase in public employment that followed the advent of democracy after Franco's death. Between 1980 and 2001, public employment grew by $133.0 \%$, increasing from 1.4 to 3.2 million jobs. We start by analyzing the determinants of this public sector job expansion across cities. Two important results emerge. First, more public sector jobs were created in cities experiencing negative labor demand shocks, suggesting that public employment is used by governments to reduce spatial income inequalities. Specifically, we find that one public job is created for 5 private sector jobs destroyed. Second, the provincial capitals (established in 1833) experienced a more than proportionate increase in public employment between 1980 and 2001. Specifically, being a capital city implied an additional 1.6 public sector jobs each decade per 100 inhabitants in the base year. This result is the basis for our Two Stage Least Squares (TSLS) strategy which consists in using the capital status of cities to instrument for changes in public sector employment. The TSLS estimates indicate 
that one additional public sector job increases non-tradable employment by 0.9 jobs and the workforce by 2.3 individuals. For the tradable sector, we find (statistically insignificant) multipliers that are close to zero. These estimates imply that increasing public employment leaves the unemployment rate largely unchanged. The simulation and regression estimates of the tradable multiplier differ. While they are negative in the simulations, they are close to zero in the regressions. One reason might be that, in practice, not every manufacturing firm sell all outputs to national or international markets. For instance, local customers might be important for firms in the publishing and printing or the furniture industries. In any case, note that the regression results do also imply that public employment creates cities with a low specialization level in tradable activities.

The papers that are closest to ours are Faggio and Overman (2014) and Becker et al. (2018) ${ }^{2}$. The first paper estimates the local labor market effects of public employment in England. Their main results, based on 2003-2007 employment changes at the English Local Authority level, indicate that one public sector jobs creates 0.5 jobs in the non-tradable sector and destroys about 0.4 jobs in the tradable sector, implying a very small positive effect on private employment. When examining a longer time horizon (1999-2007), their results suggest that public employment completely crowds-out private employment with a large negative multiplier on the tradable sector. Becker et al. (2018) use the relocation of the German federal government, from Berlin to Bonn after the Second World War, as a natural experiment to evaluate the impact of public employment on private employment. They find that, in the long run, each additional public sector job reduces employment in the manufacturing sector by 0.19 and creates about 1.05 jobs in the non-tradable sector, with a positive private sector multiplier of 0.86 . Our results are, thus, more in line with the findings of Becker et al. (2018) ${ }^{3}$. Interestingly, Faggio and Overman (2014) do not find effects on city size which suggests that, in England, labor demand shocks do not trigger large population responses. As the authors recognize, this might be caused by a highly restrictive planning system (Hilber and Vermeulen, 2016).

We contribute to this literature that estimates employment multipliers of public sector jobs by studying the long-run impact of public employment in a time period in which the Spanish public sector developed, with massive, geographically heterogeneous increases in public employment. Our instrumental variables approach uses a city feature, the capital status of a city that dates back to 1833, to predict public employment growth in the period 1980-2001. Our second contribution is to develop a search and matching model that incorporates the key mecha-

\footnotetext{
${ }^{2}$ Instead of estimating public job multipliers, Moretti (2010) and Moretti and Thulin (2013) estimate the local multipliers of jobs in the tradable sector.

${ }^{3}$ Two related papers are Faggio (2015) and Faggio et al. (2018). Instead of studying the effects of public employment at the local labor market level, these two studies explore the effects of creating public jobs at the neighborhood level. The results indicate that neighborhoods in which public jobs are created experience increases in local private employment, with the effects driven by job creation in non-tradable sectors. Concretely, Faggio (2015) exploits the relocation of 25.000 public jobs away from London and South-East region to other UK destinations and Faggio et al. (2018) uses the German government move from Bonn to Berlin in the 1990s.
} 
nisms through which public employment might affect the local economy. The simulation exercises conducted in Section 3 yield employment multipliers that are broadly consistent with the instrumental variables multipliers. This helps us clarify the mechanisms through which public employment affects local labor markets. Combined with the finding of Faggio and Overman (2014) and Becker et al. (2018), the results of this paper suggest that the impact of public sector jobs on private employment depends crucially on the extent to which a positive labor demand shock is followed by population inflows. Our study also highlights that migration responses imply that the effects of public employment will be very different if one examines employment levels versus employment and unemployment rates. Specifically, we find that public sector jobs crowd-in private sector jobs but does not reduce the local unemployment rate.

Cardullo (2017) and Caponi (2017) are two related studies that analyze the impact of centralized public sector wage bargaining in a search and matching model in an economy with labor mobility and two regions that differ in productivity ${ }^{4}$. The relatively high public sector wage in the low productivity region increases private sector wages which tends to reduce private employment. Cardullo (2017) emphasizes that, despite the unintended effects of the policy, centralized wages in the public sector might benefit residents in the poor region, while Caponi (2017) concludes that the reduction of private employment in the low productivity region increases the local unemployment rate. Other recent papers using search and matching models in a spatial equilibrium framework include Beaudry et al. (2012), Kline and Moretti (2013), Beaudry et al. (2014) and Wrede (2015). One distinctive aspect of our model is the presence of a non-tradable sector that employs local workers to produce a good that is consumed locally. This allows public employment to crowd-in private employment despite the increase in private sector wages. This mechanism turns out to be important to understand the local effects of public employment at the city level both in the simulations and regression approaches.

The remainder of this paper is organized as follows. In section 2 we develop the theoretical model. Section 3 presents the calibration of the model (3.1), the main results of the model simulations (3.2) and two alternative simulations of the model (3.3). Section 4 contains the regression analysis. We describe the data and variables (4.1) before providing the institutional background and analyzing the city-level determinants of the public sector job expansion (4.2). Then, we turn to the analysis of the effects of public employment on the city's private employment, population and unemployment rate (4.3). Finally, section 5 concludes.

\footnotetext{
${ }^{4}$ Our paper is also related to the literature studying the labor market effects of public employment at the national level. Burdett (2012), Gomes (2018, 2015), Bradley et al. (2017) and Albrecht et al. (2017) use search and matching models to analyze the effects of public sector wages and employment on labor market outcomes. Algan et al. (2002) is an empirical paper analyzing the effects of public employment at the country level using a long panel of OECD countries.
} 


\section{The model}

In this section we develop a search and matching model $\ddot{i}^{1 / 2}$ la Pissarides (2000) where workers can be unemployed or employed in the public sector, $g$, in the tradable sector, $t$, or in the nontradable sector, $n$. Unemployed workers can migrate. We follow Kline and Moretti (2013) and assume that the level of utility for the unemployed is fixed and is common across cities. This assumption implies that unemployed workers move at zero cost and that each city is small relative to the whole economy. This assumption is analogous to the free mobility assumption in Roback (1982). The model aim is to describe the economy of the city in the long-run and to study how increasing public sector jobs permanently affects this long-run equilibrium.

\subsection{Employment and unemployment}

Homogeneous unemployed workers enjoy the non-labor income $b$ and search for jobs in the three sectors simultaneously ${ }^{5}$. The endogenous rate at which unemployed workers find jobs in sector $i$ is $f_{i}$ with $i=g, t, n$. Meanwhile, the exogenous (industry-specific) rate at which workers separate from their jobs is $s_{i}$.

Jobs, which can be vacant, are filled via a constant returns to scale matching function, $m(u L, v L)=$ $m_{o} u^{\chi} v^{(1-\chi)} L$, where $u$ is the unemployment rate, $v$ the vacancy rate and $L$ is the labor force of each city, while $\chi$ and $m_{o}$ are the elasticity and scale matching function parameters, respectively. The tightness of the labor market is determined by $\theta$ (the city vacancies-unemployment ratio), $\theta \equiv \frac{v_{g}+v_{t}+v_{n}}{u} \equiv \frac{v}{u} 6$. The job finding rate in sector $i$ is $f_{i}(\theta)=f(\theta) \Omega_{i}$, where $f(\theta)=\frac{m(u L, v L)}{u L}$ and $\Omega_{i}$ represents the fraction of vacant jobs in each sector, $\Omega_{i}=\frac{v_{i}}{v}$. Hence, the aggregate job finding rate is $f(\theta)=f_{g}+f_{t}+f_{n}$. In turn, vacancies are filled at rate $q(\theta)=\frac{f(\theta)}{\theta}$ which is common for all sectors. According to the properties of the matching function, the higher the number of vacancies with respect to the number of unemployed workers, the easier it is to find a job, $f^{\prime}(\theta)>0$, and the more difficult it is to fill a vacancy, $q^{\prime}(\theta)<0$. Hence, the public and private sectors compete for the same (homogeneous) workers in the labor market.

\subsection{Job creation}

The public sector is a non-profit organization that posts vacancies exogenously, although these vacancies are not instantaneously filled due to matching frictions. We also assume that the wage level and the wage bill are exogenously determined as the lion's share of the public wage cost is financed by central and regional governments.

In the tradable and non-tradable sectors, firms open vacancies with a flow cost $k_{i}$ with $i=t, n$. Private firms have a technology with labor as the only input. Each filled job in the

\footnotetext{
${ }^{5}$ This technology of search is labelled as undirected search in Acemoglu (2001).

${ }^{6} \mathrm{By}$ the homogeneity of the matching function this ratio is not a function of $L$.
} 
tradable sector yields instantaneous profit equal to the difference between the marginal productivity of labor and the wage. The price of the tradable good is exogenous and normalized to one as tradable goods are sold in national (or international) markets, implying that the instantaneous profit amounts to $A_{t}(L)-w_{t}$. We follow the literature and consider that productivity increases with city size due to agglomeration economies ${ }^{7}$. Specifically, the marginal productivity of labor is given by $A_{t}(L)=A_{t_{0}} L^{\zeta}$, where $0<\zeta<1$ and $A_{t_{0}}$ captures the exogenous technological level in the tradable sector. In turn, the instantaneous profit of the non-tradable sector is equal to $p_{n}-w_{n}$, which increases with the (endogenous) price of the non-tradable good, $p_{n}{ }^{8}$.

Thus, the value of vacancies $V_{t}$ and $V_{n}$, and the value of a job in the tradable and nontradable sectors, $J_{t}$ and $J_{n}$, are represented by the following Bellman equations:

$$
\begin{gathered}
r V_{i}=-k_{i}+q(\theta)\left(J_{i}-V_{i}\right), \quad \text { with } i=t, n, \\
r J_{t}=A_{t}(L)-w_{t}+s_{t}\left(V_{t}-J_{t}\right), \\
r J_{n}=p_{n}-w_{n}+s_{n}\left(V_{n}-J_{n}\right) .
\end{gathered}
$$

Firms in the tradable and non-tradable sectors will open vacancies until the expected value of vacancies becomes zero, $r V_{i}=0$ with $i=t, n$. Thus, using the free entry condition, equation 1 and equations 2 and 3 we get:

$$
\begin{gathered}
\frac{k_{t}}{q(\theta)}=\frac{A_{t}(L)-w_{t}}{\left(r+s_{t}\right)}, \\
\frac{k_{n}}{q(\theta)}=\frac{p_{n}-w_{n}}{\left(r+s_{n}\right)} .
\end{gathered}
$$

Equations 4 and 5 are the standard job creation curves that characterize the marginal condition for the demand of labor in the tradable and non-tradable sectors, respectively. More jobs are created if wages, vacancy costs and labor market tightness are low and if marginal revenue $\left(A_{t}(L)\right.$ or $\left.p_{n}\right)$ is high. We assume that profits accrue to absentee firm owners that do not live in the city.

\footnotetext{
${ }^{7}$ See Melo et al. (2009) for a meta-analysis and Combes and Gobillon (2015) for a recent review of the empirics of agglomeration economies.

${ }^{8}$ We do not consider agglomeration effects in the non-tradable sector as there is less room for productivity increases in that sector (Moretti (2012), p.57).
} 


\subsection{Workers}

Workers' utility is determined by the consumption levels of a tradable good, a non-tradable good and land. The utility level that a worker gets if living in city $c$ depends on nominal income, $y=\left\{b, w_{g}, w_{t}, w_{n}\right\}$ and the local prices of the non-tradable good, $p_{n}$, and land, $p_{c}$. We assume that the utility function takes the Cobb-Douglass form, which implies that, for a given level of income, the utility level of residing in city $c$ is $y(1-\phi-\delta)^{(1-\phi-\delta)}\left(\frac{\phi}{p_{n}}\right)^{\phi}\left(\frac{\delta}{p_{c}}\right)^{\delta}=\frac{y}{P}$, where $P$ is the city price index ${ }^{9}$.

$$
P=\left(\frac{1}{1-\phi-\delta}\right)^{(1-\phi-\delta)}\left(\frac{p_{n}}{\phi}\right)^{\phi}\left(\frac{p_{c}}{\delta}\right)^{\delta}
$$

The parameters $\phi$ and $\delta$ reflect workers' preferences for the non-tradable good and land, respectively, as well as being the income shares spent on these two goods. The values for unemployment, $U$, and employment in the public, $W_{g}$, tradable, $W_{t}$, and non-tradable, $W_{n}$, sectors are given by the following expressions:

$$
\begin{gathered}
r U=\frac{b}{P}+f_{g}\left(W_{g}-U\right)+f_{t}\left(W_{t}-U\right)+f_{n}\left(W_{n}-U\right), \\
r W_{i}=\frac{w_{i}}{P}+s_{i}\left(U-W_{i}\right), \quad \text { with } i=g, t, n .
\end{gathered}
$$

We assume that the level of utility for the unemployed is fixed and is common across cities $(r U=z)$. This assumption implies that unemployed workers move at zero cost and that each city is small relative to the whole economy. Taking equation 7 and $r U=z$ implies that, in equilibrium, if the labor market prospects of a city improve (high wages, high job finding rates and/or low job separation rates), then the city must become a more expensive place to live-in (higher price index). Using these two equations together with equation 8 we get:

$$
r U=\frac{b}{P}+f_{g}\left(\frac{\frac{w_{g}}{P}-z}{r+s_{g}}\right)+f_{t}\left(\frac{\frac{w_{t}}{P}-z}{r+s_{t}}\right)+f_{n}\left(\frac{\frac{w_{n}}{P}-z}{r+s_{n}}\right)=z .
$$

Equation 9 appears as a consequence of workers' mobility and relates the unemployment value, $z$, to the city's land price and job market prospects.

\footnotetext{
${ }^{9}$ In our model, more public employment does not translate into a higher provision of local public goods and services and, thus, it does not increase city amenities. We take this modeling approach because, as will discuss below, public employees in capital cities provide public goods and services (administrative services, universities and hospitals) that benefit both residents and non-residents.
} 


\subsection{Wage determination}

The next assumption is that wages in the tradable and non-tradable sectors are set through Nash bargaining. The Nash solution is the wage that maximizes the weighted product of the worker's and firm's net return from the job match in each sector, $\left(W_{i}-U\right)^{\beta}\left(J_{i}-V_{i}\right)^{1-\beta}$, where the parameter $\beta$ represents the worker's bargaining power ${ }^{10}$. Notice that while the value functions of workers (equations 7 to 8 ) are expressed in terms of the local price index, the value functions of firms (equations 1 to 3 ) appear in nominal terms. This asymmetry takes place because, unlike workers, firm owners do not live and consume in the city. Therefore, firms are worried about output prices and nominal wages while workers are concerned about real wages. The wage equations from this maximization problem are ${ }^{11}$ :

$$
\begin{gathered}
w_{t}=\beta A_{t}(L)+(1-\beta) z P, \\
w_{n}=\beta p_{n}+(1-\beta) z P .
\end{gathered}
$$

Frictions and bargaining result in wages in the private sector that depend not only on the sector productivity but also on the city price index, $P$, which is internalized in the wage negotiation. Specifically, a higher cost of living in the city will increase the wages in the private sector.

\subsection{Closing the model}

To fully characterize the dynamics of this economy, we need to define the law of motion for the unemployment rate $\left(\dot{u}=s_{g} e_{g}+s_{t} e_{t}+s_{n} e_{n}-f_{g} u-f_{t} u-f_{n} u\right.$ ), and for the employment rates in the public, tradable and non-tradable sectors $\left(\dot{e}_{i}=f_{i} u-s_{i} e_{i}\right.$, with $\left.i=g, t, n\right)$. Then, the unemployment rate and the employment rates in the public, tradable and non-tradable sectors in steady state are:

$$
\begin{gathered}
u=\frac{s_{g} s_{t} s_{n}}{\left[s_{t} s_{n} s_{g}+s_{g} s_{t} f_{n}+s_{g} f_{t} s_{n}+f_{g} s_{t} s_{n}\right]}, \\
e_{i}=\frac{f_{i}}{s_{i}} u, \quad \text { with } i=g, t
\end{gathered}
$$

\footnotetext{
${ }^{10}$ The presence of bilateral Nash bargaining between the firm and the worker ensures that both the firm and worker surpluses are positive $\left(J_{i}-V_{i}>0\right.$ and $\left.W_{i}-U>0\right)$. The sufficient conditions are $A_{t}(L) / P>z$ and $p_{n} / P>z$ in the tradable and non-tradable sectors, respectively. Additionally, the acceptance of a job offer from the public sector requires $w_{g} / P>z$.

${ }^{11}$ The derivation of the first order conditions from this maximization problem and their resulting wage equations 10 and 11 are presented in Appendix A.1.
} 


$$
e_{g}+e_{t}+e_{n}+u=1
$$

Notice that, according to equation 14, the levels of unemployment and employment in the public, tradable and non-tradable sectors are $u L, e_{g} L, e_{t} L$ and $e_{n} L$, respectively. In order to close the model, the markets for the non-tradable good and land must clear. The non-tradable good must be purchased by local workers.

$$
\phi\left(w_{g} e_{g}+w_{t} e_{t}+w_{n} e_{n}+b u\right)=p_{n} e_{n}
$$

Equation 15 guarantees that the local price of the non-tradable good clears the market. Finally, following Kline and Moretti (2013), we assume that land rents accrue to absentee land owners and that the land price is increasing with city size according to:

$$
p_{c}=L^{\eta}
$$

The system of equations that characterize the equilibrium of the model are deferred to the Appendix B.

\subsection{The mechanisms of the model}

We are interested in analyzing the local labor markets effects of expanding public employment in contexts in which public wages are relatively high. Suppose there is an increase in $f_{g}$, the job finding rate in the public sector, resulting from an exogenous increase in the public sector vacancy rate, $v_{g}$. These job opportunities in the public sector will attract workers to the city. The inflow of workers increases city size, $L$, which in turn, increases the price of land, $p_{c}=L^{\eta}$ and the cost to live in the city $(P)$ as workers spent a fraction $\delta$ of their income in land. The non-arbitrage condition in equation 9 determines the rate at which (indifferent) workers trade better labor market prospects against a higher local price index, $P$.

As the local cost of living is internalized in the wage bargaining process (equations 10 and 11 ), the inflow of workers in the city causes private sector wages ( $w_{t}$ and $w_{n}$ ) to increase. These wage increases contribute to decrease the employment rates in the private sector as the job creation curves (equations 4 and 5) indicate. In the tradable sector, the wage increase might be compensated by the productivity gain caused by agglomeration economies, $A_{t}(L)$. In the nontradable sector, the market clearing condition for the non-tradable good (equation 15) allows $p_{n}$ to increase as a response to the higher local demand for non-tradables.

The focus of this paper is to estimate the private sector employment changes that result from 
an expansion of the local employment in the public sector. In our model, the employment level in one sector is the employment rate in the sector times the size of the city. Hence, changes in employment are determined by employment rate changes and changes in city size, $L$. Finally, public employment will reduce the local unemployment rate unless the increase in the public employment rate is completely offset by employment rate reductions in the private sector.

\section{Calibration and simulated results of the model}

\subsection{Calibration}

We calibrate the model to match the labor market characteristics of the average Spanish city with transition rates defined at quarterly frequencies. Table 1 summarizes all the calibrated parameters and presents the steady state values of the endogenous variables. The real interest rate is fixed at $r=0.012$, which is consistent with an annual interest rate of $4.8 \%$. We target the 2001 city averages in terms of the unemployment rate (15.6\%) and the employment rates in the public sector $(20.9 \%)$, the tradable sector (15.8\%) and the non-tradable sector $(47.7 \%)$. Using the Spanish Labor Force Survey (SLFS) and adopting the methodology applied in Silva and Vázquez-Grenno (2013), we calculate the separation rates in the three sectors considered. While the separation rate in the public sector is $s_{g}=0.009$, in the tradable and non-tradable sectors these rates are higher and virtually identical with $s_{t}=s_{n}=0.015$. Combining the job separation rates, the employment rates and the unemployment rate with $\dot{e_{g}}=\dot{e_{t}}=\dot{e_{n}}=\dot{u}=0$ delivers the job finding rates $f_{g}=0.012, f_{t}=0.015$ and $f_{n}=0.046$, which implies an aggregate job finding rate equals to $f(\theta)=0.0731$. The sectorial fraction of vacancy rates $\Omega_{i}$ are obtained using $f(\theta)$ and $f_{i}=f(\theta) \Omega_{i}$. Thus, we set $\Omega_{g}=0.165, \Omega_{t}=0.208$ and $\Omega_{n}=0.627$.

As for wages, we normalize the wage in the public sector to one $\left(w_{g}=1\right)$. Controlling for individual characteristics, Hospido and Moral-Benito (2016) find a wage gap of $20 \%$ between public and private sector workers. Similarly, we estimate the wage gap between the tradable and the non-tradable sectors using the Spanish Continuous Sample of Working Lives in 2005 (Muestra continua de Vidas Laborales, MCVL). We find a gap of $13.2 \%$ after controlling for individual characteristics (age, age square, gender and education). These wage gaps leave us with $w_{t}=0.913$ and $w_{n}=0.807$.

According to Eurostat, labor productivity in the Spanish tradable sector was $45.7 \%$ higher than personnel costs ${ }^{12}$. Thus, we set labor productivity at $A_{t}(L)=w_{t} * 1.457=1.331$. As for agglomeration economies, Ciccone and Hall (1996) and Rosenthal and Strange (2008) find an elasticity of (total factor) productivity with respect to density of around 4-5\%. One concern with these studies is that highly-skilled workers are positively selected into the largest cities, thus

\footnotetext{
${ }^{12} 2008$-2010 average from Eurostat - Structural Business Statistics.
} 
over-estimating the effect of city size on productivity (Combes and Gobillon, 2015). Therefore, we set this elasticity at $3 \%$, i.e. $\zeta=0.03$. We normalize the labor force to one $(L=1)$ which implies $A_{o_{t}}=1.331$ given $A_{t}(L)=A_{t_{0}} L^{\zeta}$ and $p_{c}=1$ given equation 16 . We assume that $\eta$, the elasticity of the land price with respect to city size, is 0.70 as the midpoint of the range that has been recently estimated by Combes et al. (2016a).

Following Shimer (2005), we normalize $\theta$ to one ${ }^{13}$. Once the $\Omega_{i}$ 's, $u$ and $\theta$ are known, we obtain the vacancy rates for all sectors using $\Omega_{i}=\frac{v_{i}}{v}$ and $\theta=\frac{v}{u}$. We obtain $v_{g}=0.026, v_{t}=0.032$ and $v_{n}=0.098$ and, thus, $v=v_{t}+v_{n}+v_{g}=0.156$. Finally, according to $q(\theta)=\frac{f(\theta)}{\theta}$, the vacancy filling rate is $q(\theta)=0.073$. Pissarides and Petrongolo (2001) identify the matching function elasticity parameter as being in the $0.5-0.7$ range. We take 0.6 as our reference and, thus, we set $\chi=0.6$. Given that we know the job finding rates and $\theta$, we can then use $f=m_{o} \theta^{1-\chi}$ to obtain the matching function scale parameter $m_{o}=0.073$.

The last two parameters determined by data are the income shares spent on the non-tradable good and land. For the former share, we use data from the Household Budget Survey (HBS) for 2006. We set the share of income that workers spend on the non-tradable good, $\phi$, at $0.6^{14}$. In order to determine the income share spent on land, we multiply the income share dedicated to housing by the share of land in housing values. We set the first quantity at 0.293 , which is in between to the values reported for the US by Davis and Ortalo-Magne (2011) and for France by Combes et al. (2016a) ${ }^{15}$. The second quantity, the share of land in housing values, is directly available from the BBVA capital stock series. This quantity closely follows the Spanish housing periods of boom and bust. We take 0.233 , the average value for the pre-boom period (1995-1998), which is very similar to the estimates reported by Albouy (2009) and Combes et al. (2016b) for the US and French economies, respectively. The product of these two quantities is very close to $7 \%$ and, thus, we set $\delta=0.07$. The income share spent on tradable goods is thus obtained as $1-\phi-\delta$ which amounts to 0.33 .

Knowing $w_{t}, A_{t}(L), q(\theta), r$ and $s_{t}$, we can use equation 4 to find the vacancy cost in the tradable sector $k_{t}$. There are no other variables or parameters that can be identified by a single equation. The price of the non-tradable good, $p_{n}$, along with the parameters $b$ (non-labor in-

\footnotetext{
${ }^{13}$ If we divide $\theta$ by one half, then the matching parameter $m_{o}$ needs to be multiplied by $2^{(1-\chi)}$ in order to keep our calibrated job finding rate $f(\theta)$ constant. This multiplies the job filling rate $q(\theta)$ by a factor of two. Since we also have set $w_{t}, w_{n}, w_{g}$ and $A_{t}(L)$ to target the ratio of productivity to wages in the tradable sector and the wage gaps across sectors, then equations 4 and 5 imply that the vacancy costs $k_{i}$ will be multiplied by two to keep $k_{i} / q(\theta)$ constant. Thus, changing $\theta$ will proportionally modify $m_{o}, k_{i}$ and $q(\theta)$, keeping unchanged the rest of parameters and variables.

${ }^{14}$ It is not always obvious whether to classify household expenditure as tradable or non-tradable spending at the city level. In general, we consider services to be non-tradable goods.

${ }^{15}$ Imputed rents from the Living Conditions Survey (LCS) look abnormally low in Spain. We take rental values from a leading listing website (Fotocasa). In 2012, the average rent was 7.220 euros a month per square meter. The average dwelling in Spain is $90.6 \mathrm{~m}^{2}$ (2011 Population and Housing Census) which gives us an annual rent of 7,850 euros. If we take the average household income in Spain (26,775 euros according to LCS), we obtain a share of income spent on housing of 0.293 .
} 
come), $\beta$ (the workers' bargaining power), $z$ (the value of unemployment) and $k_{n}$ (the vacancy cost in the non-tradable sector) are jointly determined by equations 5, 9, 10, 11 and 15.

Table 1: Calibrated parameter values

\begin{tabular}{|c|c|c|}
\hline Parameters & Value & Source/Target \\
\hline Interest rate, $r$ & 0.012 & Data \\
\hline Separation rate public sector, $s_{g}$ & 0.009 & SLFS \\
\hline Separation rate tradable sector, $s_{t}$ & 0.015 & SLFS \\
\hline Separation rate non-tradable sector, $s_{n}$ & 0.015 & SLFS \\
\hline Matching function elasticity parameter, $\chi$ & 0.600 & (Pissarides and Petrongolo, 2001) \\
\hline Matching function scale parameter, $m_{o}$ & 0.073 & Matching function \\
\hline Wage public sector, $w_{g}$ & 1.000 & Normalization \\
\hline Exogenous productivity tradable sector, $A_{t o}$ & 1.331 & Eurostat \& $L=1$ \\
\hline Agglomeration economies' elasticity, $\zeta$ & 0.030 & (Combes and Gobillon, 2015) \\
\hline Land cost to city size elasticity, $\eta$ & 0.700 & (Combes et al., 2016a) \\
\hline Non-tradable good income share, $\phi$ & 0.600 & HBS \\
\hline Land income share, $\delta$ & 0.070 & LCS, BBVA \& Fotocasa \\
\hline Workers' bargaining power, $\beta$ & 0.313 & Solves 5, 9, 10, 11 and 15 \\
\hline Non-labor income, $b$ & 0.315 & Solves $5,9,10,11$ and 15 \\
\hline Unemployment utility, $z$ & 0.308 & Solves $5,9,10,11$ and 15 \\
\hline Vacancy cost tradable sector, $k_{t}$ & 1.130 & Solves 4 \\
\hline Vacancy cost non-tradable sector, $k_{n}$ & 0.497 & Solves $5,9,10,11$ and 15 \\
\hline \multicolumn{3}{|l|}{ Variables } \\
\hline Public employment rate, $e_{g}$ & 0.209 & 2001 Census \\
\hline Tradable employment rate, $e_{t}$ & 0.158 & 2001 Census \\
\hline Non-tradable employment rate, $e_{n}$ & 0.477 & 2001 Census \\
\hline Unemployment rate, $u$ & 0.156 & 2001 Census \\
\hline Labor market tightness, $\theta$ & 1.000 & Normalization \\
\hline Wage tradable sector, $w_{t}$ & 0.913 & MCVL \\
\hline Wage non-tradable sector, $w_{n}$ & 0.807 & MCVL \\
\hline Labor force, $L$ & 1.000 & Normalization \\
\hline Job finding rate public sector, $f_{g}$ & 0.012 & Solves 13 \\
\hline Job finding rate tradable sector, $f_{t}$ & 0.015 & Solves 13 \\
\hline Job finding rate non-tradable sector, $f_{n}$ & 0.046 & Solves 14 \\
\hline Land price, $p_{c}$ & 1.000 & Solves 16 \\
\hline Productivity tradable sector, $A_{t}$ & 1.331 & Eurostat \& $L=1 \& A_{t}(L)=A_{t_{0}} L^{\zeta}$ \\
\hline Non-tradable good price, $p_{n}$ & 0.990 & Solves $5,9,10,11$ and 15 \\
\hline
\end{tabular}

\subsection{Simulated results}

Table 2 presents the simulated results of the model with a vacancy creation policy scenario that targets increases of 25, 50 and $100 \%$ in the level of public employment, $L e_{g}$. The size of these public employment increases is consistent with the public sector employment expansions ob- 
served in Spanish cities in the period 1980-2001. These scenarios correspond to increases in the public vacancy rate, $v_{g}$, from 0.026 to $0.030,0.033$ and 0.039 , respectively.

The new relatively well paid jobs in the public sector attracts workers to the city. As a result, this increases the price of land and then, the city price index. Since the local cost of living is internalized in the wage bargaining process, expanding public sector employment increases wages in the private sector. In the tradable sector, larger city size increases productivity due to agglomeration economies, $A_{t}(L)$. However, the productivity gains are offset by the higher wages and employment in the tradable sector is reduced. The simulations imply employment multipliers in the tradable sector of -0.396 and -0.458 , which can be interpreted as the number of jobs lost for each additional worker in the public sector. In the non-tradable sector, higher local demand translates into higher prices for the non-tradable good $p_{n}$, which in this case offset the wage increase. The simulations imply that one public sector job creates between 0.737 and 0.824 jobs in the non-tradable sector.

Table 2 also indicates that the positive effects of public employment on city size are large. Specifically, an additional public job increases the city's labor force by 1.464 to 1.644 workers. As explained above, the employment multipliers found are the result of changes in city size and changes in employment rates. If we take the scenario of a $50 \%$ increase in public employment, the share of workers employed in the tradable sector decreases significantly from 0.158 to 0.098 while, in the non-tradable sector, the employment rate remains almost constant (from 0.477 to 0.481), which is consistent with the fact that production in the non-tradable sector must equal a constant share of local consumption. The unemployment rate decreases as the increase in the employment rate in the public sector (from 0.209 to 0.270 ) is larger than the employment rate decrease in the tradable sector. Overall, the unemployment is reduced from 0.156 to 0.152 . The population inflow weakens the link between more jobs in the city and a lower unemployment rate.

Table 2: Benchmark simulated results with an increase in public employment

\begin{tabular}{|c|c|c|c|c|c|c|c|c|c|c|c|c|c|c|}
\hline & 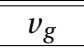 & $\overline{\theta \theta}$ & 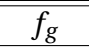 & $\bar{f} f_{t}$ & $\overline{f_{n}}$ & $\overline{p_{n}}$ & 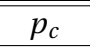 & $\overline{w_{t}}$ & $w_{n}$ & $\overline{L L e_{g}}$ & $\overline{L L e_{t}}$ & 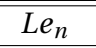 & 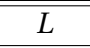 & 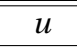 \\
\hline \multicolumn{15}{|l|}{ Baseline } \\
\hline & 0.026 & 1.000 & 0.012 & 0.015 & 0.046 & 0.990 & 1.000 & 0.913 & 0.807 & 0.209 & 0.158 & 0.477 & 1.000 & 0.156 \\
\hline \multicolumn{15}{|c|}{$25 \%$ increase in public employment } \\
\hline & 0.030 & 0.996 & 0.014 & 0.012 & 0.047 & 0.995 & 1.059 & 0.918 & 0.811 & 0.261 & 0.137 & 0.520 & 1.086 & 0.154 \\
\hline Multipliers & & & & & & & & & & & -0.396 & 0.824 & 1.644 & \\
\hline \multicolumn{15}{|c|}{$50 \%$ increase in public employment } \\
\hline & 0.033 & 0.993 & 0.016 & 0.010 & 0.047 & 0.998 & 1.113 & 0.921 & 0.815 & 0.314 & 0.114 & 0.560 & 1.165 & 0.152 \\
\hline Multipliers & & & & & & & & & & & -0.420 & 0.791 & 1.576 & \\
\hline \multicolumn{15}{|c|}{$100 \%$ increase in public employment } \\
\hline & 0.039 & 0.987 & 0.019 & 0.005 & 0.049 & 1.004 & 1.206 & 0.927 & 0.822 & 0.418 & 0.062 & 0.631 & 1.306 & 0.149 \\
\hline Multipliers & & & & & & & & & & & -0.458 & 0.737 & 1.464 & \\
\hline
\end{tabular}

Note: Multipliers are calculated as the employment or labor force change divided by the employment increase in the public sector. 


\subsection{Alternative simulations of the model}

In this section we first consider the model without geographic mobility. Then, we study the relationship between the size of the multipliers and the magnitude of the public sector wage gap.

\subsubsection{The model without labor mobility}

In our model, the fact that the price of land increases with city size acts as a congestion force and limits the inflow of workers when the city experiences a positive labor demand shock. However, we neglect the existence of moving costs and idiosyncratic preferences for locations that would limit the migration responses in our model. In order to explore the predictions of the model in instances in which labor mobility is low, we study the extreme case of no mobility. City size is then fixed, $L=1$, which implies that the productivity in the tradable sector and the price of land are fixed. Since there is no mobility, it is no longer true that $r U=z$. Then, equations 9 and 16 can be dropped and $A_{t}(L)$ becomes a constant term. Besides, the fact there is not a reservation utility for the unemployed changes the wage equations which are derived and shown in Appendix A.2. Due to frictions and bargaining, the wages in the private sector depend on the wage and the job finding and separation rates in the public sector. Table 3 shows the simulated results with an increase in the public sector vacancy rate from 0.026 to 0.038 (a $50 \%$ increase in the level of public employment).

Table 3: Simulated results without labor mobility across cities

\begin{tabular}{lcccccccccccccc}
\hline \hline & $v_{g}$ & $\theta$ & $f_{g}$ & $f_{t}$ & $f_{n}$ & $p_{n}$ & $p_{c}$ & $w_{t}$ & $w_{n}$ & $L e_{g}$ & $L e_{t}$ & $L e_{n}$ & $L$ & $u$ \\
\hline Baseline & 0.026 & 1.000 & 0.012 & 0.015 & 0.046 & 0.990 & 1.000 & 0.913 & 0.807 & 0.209 & 0.158 & 0.477 & 1.000 & 0.156 \\
\hline $\begin{array}{r}\text { 50\% increase in public employment } \\
0.038\end{array}$ & 0.969 & 0.019 & 0.005 & 0.048 & 0.997 & 1.000 & 0.921 & 0.817 & 0.314 & 0.052 & 0.484 & 1.000 & 0.150 \\
Multipliers & & & & & & & & & & $-\mathbf{1 . 0 1 4}$ & $\mathbf{0 . 0 6 8}$ & $\mathbf{0 . 0 0 0}$ & \\
\hline \hline
\end{tabular}

Note: Multipliers are calculated as the employment change divided by the employment increase in the public sector.

In contrast to the case in which geographic mobility was considered, public employment clearly crowds-out private employment. While one extra job in the public sector destroys about 1 job in the tradable sector, it only creates 0.068 jobs in the non-tradable sector. As discussed above, the tradable sector is more negatively affected than the non-tradable sector as an increase in the number of public employees does not increase the demand for locally produced tradable goods. Besides, productivity in this sector does not increase as city size is fixed. Since one public sector job destroys less than one job in the private sector, unemployment is reduced, falling from 0.156 to 0.150 . In this scenario, the link between more public sector jobs and less unemployment is not weakened by the inflow of workers but rather by the destruction of private sector jobs. 
These simulations show that whether public employment crowds-in or crowds-out private employment depends crucially on the extent to which city size increases following a public employment expansion. In fact, even if workers are mobile, public employment can not trigger an inflow of workers if land supply is very inelastic, which results in public employment crowdingout private jobs. Indeed, the simulations (not reported here for reasons of space) indicate that the elasticity of land price with respect to city size, $\eta$, together with the income share spent on land, $\delta$, are the key parameters governing whether (and the extent to which) public employment crowds-in or crowds-out private employment.

\subsubsection{Size of multipliers and the public wage premium}

As explained above, the public sector wage gap in Spain has been very large. In order to assess the degree to which this affects the multipliers, we simulate two alternative scenarios that differ in the size of the wage gap. In each scenario, we recalibrate the model maintaining the rest of the targets and simulating the effect of an increase in public employment of $50 \%$. First, we reduce the public sector wage gap to $10 \%$ while, later, we increase it to $30 \%$. The baseline scenario is reproduced here for the ease of comparison, and it corresponds to a public sector wage gap of $20 \%$. Table 4 shows the simulated results.

Table 4: Simulation results: Size of multipliers and the public wage premium

\begin{tabular}{|c|c|c|c|c|c|c|c|c|c|c|c|c|c|c|}
\hline & $v_{g}$ & $\overline{\theta \theta}$ & $\bar{f}_{g}$ & 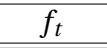 & $\bar{f}_{n}$ & $p_{n}$ & $p_{c}$ & $w_{t}$ & $w_{n}$ & $\overline{L L e_{g}}$ & $\overline{L L e_{t}}$ & $2 L e_{n}$ & 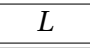 & 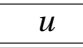 \\
\hline \multicolumn{15}{|c|}{ Baseline with $10 \%$ public wage gap } \\
\hline & 0.0257 & 1.000 & 0.012 & 0.015 & 0.046 & 1.072 & 1.000 & 0.996 & 0.880 & 0.209 & 0.158 & 0.477 & 1.000 & 0.156 \\
\hline \multicolumn{15}{|c|}{$50 \%$ increase in public employment with $10 \%$ public wage gap } \\
\hline & 0.0372 & 0.998 & 0.018 & 0.007 & 0.048 & 1.074 & 1.026 & 0.999 & 0.882 & 0.314 & 0.072 & 0.497 & 1.037 & 0.150 \\
\hline Multipliers & & & & & & & & & & & -0.826 & 0.189 & 0.357 & \\
\hline \multicolumn{15}{|c|}{ Baseline with $20 \%$ public wage gap } \\
\hline & 0.026 & 1.000 & 0.012 & 0.015 & 0.046 & 0.990 & 1.000 & 0.913 & 0.807 & 0.209 & 0.158 & 0.477 & 1.000 & 0.156 \\
\hline \multicolumn{15}{|c|}{$50 \%$ increase in public employment with $20 \%$ public wage gap } \\
\hline & 0.033 & 0.993 & 0.016 & 0.010 & 0.047 & 0.998 & 1.113 & 0.921 & 0.815 & 0.314 & 0.114 & 0.560 & 1.165 & 0.152 \\
\hline Multipliers & & & & & & & & & & & -0.420 & 0.791 & 1.576 & \\
\hline \multicolumn{15}{|c|}{ Baseline with $30 \%$ public wage gap } \\
\hline & 0.0257 & 1.000 & 0.012 & 0.015 & 0.046 & 0.921 & 1. & 0.843 & 0.744 & 0.209 & 0.158 & 0.477 & 1.000 & 0.156 \\
\hline \multicolumn{15}{|c|}{$50 \%$ increase in public employment with $30 \%$ public wage gap } \\
\hline & 0.031 & 0.991 & 0.015 & 0.0011 & 0.047 & 0.931 & 1.160 & 0.853 & 0.755 & 0.314 & 0.138 & 0.595 & 1.237 & 0.154 \\
\hline Multipliers & & & & & & & & & & & -0.190 & 1.131 & 2.263 & \\
\hline
\end{tabular}

Note: Multipliers are calculated as the employment or labor force change divided by the employment increase in the public sector.

The simulations indicate that higher public sector wages increase the positive multiplier effects of public employment. Increasing the public wage gap from 10 to $30 \%$ increases the estimated employment multipliers from -0.826 to -0.190 in the tradable sector, and from 0.189 to 1.131 in the non-tradable sector. Similarly, the labor force multiplier increases from 0.357 to 2.263. It might seem counterintuitive that the multiplier for the tradable sector becomes less negative when the wage gap increases as, in the end, the wage in the tradable sector is increas- 
ing more. There are two different effects that explain this result. First, note that productivity in the tradable sector also increases more due to agglomeration economies, $A_{t}(L)$. Second, the target of the exercise is to increase employment in the public sector by $50 \%$. This can be reached either by an increase in the employment rate (as in Table 3), or more generally, by a combination of an increase in the employment rate and an expansion of the size of the city. When the wage gap is larger, the inflow of people is also larger, implying that to reach a $50 \%$ increase in public employment the public employment rate needs to increase less $(9.4,6.1$ and 4.5 percentage points increase in the 10, 20 and $30 \%$ wage gap scenarios). The fact that the public employment rate grows less means that the vacancy rate in the public sector $\left(v_{g}\right)$ also grows less. As a result, the expansion in public employment has a smaller impact on the labor market tightness when the public wage gap is large. Since opening vacancies is less costly with a labor market that is less tight, the employment rate in the tradable sector ends up falling less when the wage gap is larger (8.9, 6.1 and 4.5 percentage points decrease in the 10, 20 and $30 \%$ wage gap scenarios).

\section{Reduced-form estimates: Evidence from the late development of the Spanish public sector: $1980-2001$}

In this section, using regression analysis, we estimate the city-level effects of public sector job expansions. Since we are interested in the long-run effects of public employment (changes between steady states in terms of the model developed above), we examine decadal changes (19801990 and 1990-2001) in the employment and population of Spanish cities. This exercise enables us to assess the degree to which the simulated results of the model match carefully estimated reduced-form coefficients. This section is organized as follows. After describing the data and variables used in the analysis, we provide a description of the geography of the expansion of public sector jobs. Then, we present our main instrumental variables analysis of public employment multipliers that uses a city's capital status as an instrument for local public sector employment growth. Finally, we assess the implied public employment expansion on the unemployment rate.

\subsection{Data and variables}

We draw primarily on Census data on employment and population. In the case of employment, the data are drawn from Censuses of Establishments carried out in 1980, 1990 and 2001, which contain counts of employees by municipality and by the main economic activity (2-digit level) of the establishment in which the employee works. In the case of population, we use population counts by labor market status from the 1981, 1991 and 2001 Population Censuses. We also have access to some data on employment and population from the 1970 Censuses. We then construct 
city-wide counts of these variables using the 2008 urban area definitions built by the Ministry of Housing. We work with a total of 83 cities (urban areas) whose locations and extensions are shown in Figure 1. In 2001, these cities concentrated $67 \%$ of the population ${ }^{16}$.

Figure 1: Urban areas (cities) in Spain

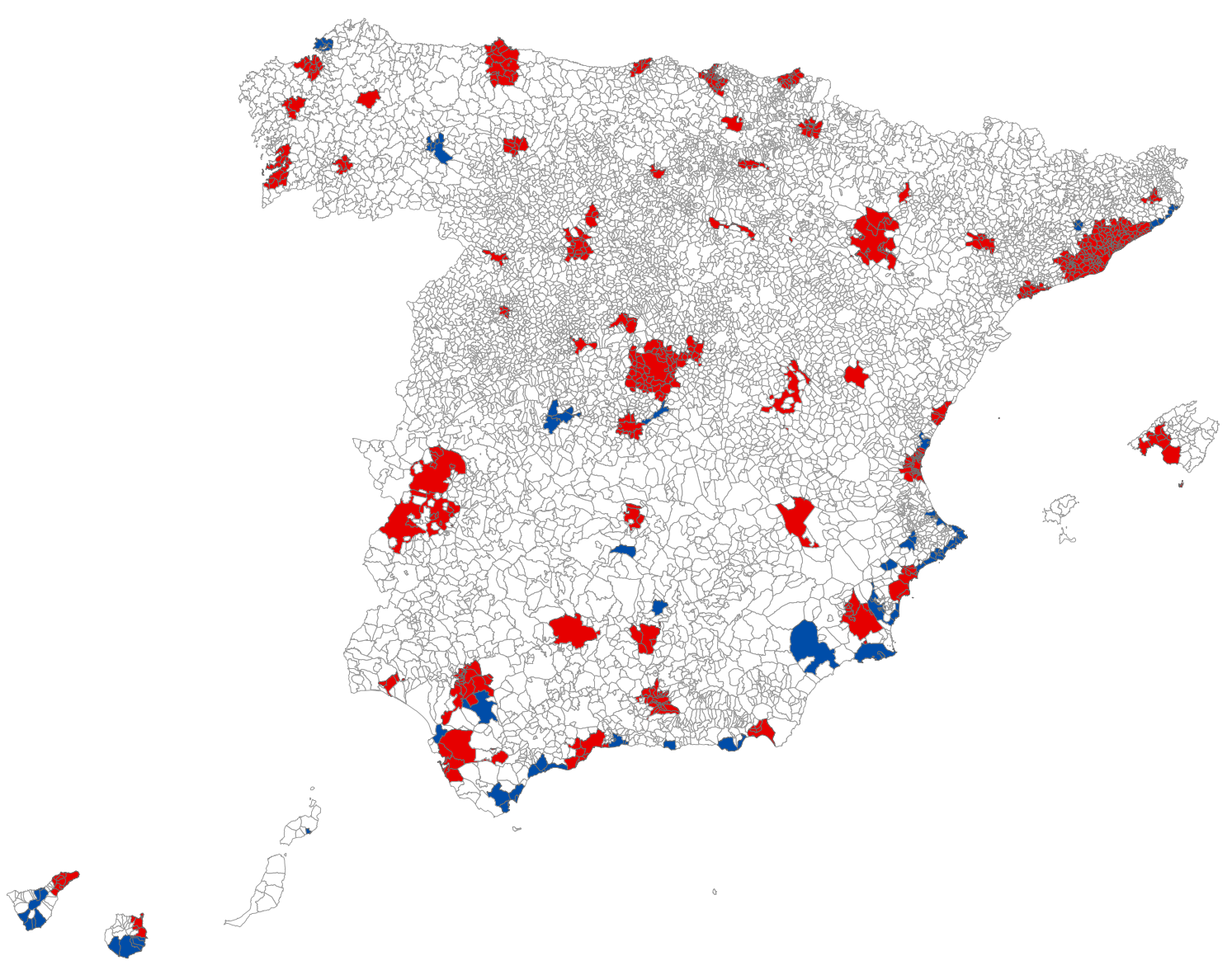

Source: Cities (urban areas) in 2008 -Ministerio de la vivienda. Capital cities (52) in red and non-capital cities (31) in blue. The map excludes Menorca (far east) and La Palma, La Gomera and El Hierro (far west) as no urban area is found in these islands.

Our public sector definition includes three industries: public administration (which includes the police and military forces), education and health. There are workers in the education and health sectors that are not public employees. Unfortunately, our data does not allow us to distinguish between private and public employees in these two activities. With this caveat in mind, we include the education and health sectors in our definition of the public sector for two reasons: First, because the majority of these workers are directly employed by governments ${ }^{17}$. Second, because there are many public services in education and health that, being partly financed by the public sector, are provided by private firms ${ }^{18}$. In Appendix $C$ we show that our main results

\footnotetext{
${ }^{16}$ We do not consider Ceuta and Melilla, the two Spanish enclaves in North Africa.

${ }^{17}$ According to the Labor Force Survey, in 1999, 67 and $61 \%$ of the workers in education and health were public sector workers.

${ }^{18}$ In primary and secondary education, teachers' salaries in the majority of privately run schools (so-called Ed-
} 
do not crucially hinge on this definition of public employment.

Total employment is the sum of employees in the public sector $\left(E_{g}\right)$, the tradable sector $\left(E_{t}\right)$ and the non-tradable sector $\left(E_{n}\right)^{19}$. We assimilate the tradable sector with the manufacturing industries, while non-tradable employment contains the workers in private activities that produce goods that can not be traded and includes the construction sector ${ }^{20}$. Our model also predicts that public sector expansions increase city size. Thus, we also consider (changes in) the citylevel (economically) active population, working age population and total population. Since in the model developed above all individuals are active in the labor market, the city size measure used there $L$ corresponds more closely to active population.

In the regression analysis, we examine decadal (1980-1990 and 1990-2001) increases in the employment and population measures detailed above relative to the city total population in the base year (1980 or 1990). The first two panels of Table 5 provide summary statistics for employment and population levels in 1980 and 2001 at the city level. The third panel reports summary statistics for the outcome variables that we examine below, namely, pooled employment and population decadal changes (1980-1990 and 1990-2001) relative to the population level at the beginning of the decade. The average city population increased by $11.5 \%$ between 1980 and 2001 while active population has grown far more $(72.9 \%)$ as women entered the labor force en masse $^{21}$. As a consequence, total employment increased by $86.0 \%$ between 1980 and 2001 . This increase was not uniform across economic sectors as the economy experienced a process of tertiarization with employment in the tradable sector growing by only $6.6 \%$ between 1980 and 2001.

In the model developed in Section 2 we have implicitly assumed that the economy is made of a large number of small cities. However, a fraction of the population live in non-urban areas. Unfortunately, the Census data that we use does not allow us to distinguish if the observed population inflows come from urban or non-urban areas. In the period that we study, Bover and Velilla (2005) document that net migrations flows across regions were small but, instead, gross migration flows were substantial. In fact, for the period 2004-2009, de la Roca and Puga (2017) using the MCVL and the same exact definition of urban area that we use, report gross migration rates across urban areas that are high and comparable to migration rates observed across US metro areas. At the same time, however, Bover and Velilla (2005) and Bover and Arellano (2002) document that in the period we study there were significant (and mostly intra-regional) net migration flows from non-urban to urban areas. These flows explain why the population growth

ucaci $i_{2}^{1} / 2 n$ concertada) are paid by regional governments. Similar arrangements also exist in the health sector.

${ }^{19}$ We do not consider agriculture, farming and mining activities as they have been treated differently in different Censuses.

${ }^{20}$ Business services are clearly tradable goods. However, the 2-digit industry classification that is available to us does not often allow us to separate business vs. personal services within an industry code.

${ }^{21}$ According to the 1981 and 2001 Censuses, between these two years the participation rate of females aged 25-64 increased from 21 to $58 \%$ 
Table 5: Employment and population in Spanish cities (1980-2001): Summary statistics

\begin{tabular}{|c|c|c|c|c|c|}
\hline Variable & Mean & Median & $\mathrm{SD}$ & Min & Max \\
\hline \multicolumn{6}{|c|}{ Employment and population levels in $1980(\mathrm{~N}=83)$} \\
\hline Tradable employment & 21,127 & 5,577 & 61,225 & 113 & 474,588 \\
\hline Non-tradable employment & 30,026 & 10,625 & 75,550 & 1,551 & 513,539 \\
\hline Total employment & 64,353 & 18,914 & 163,557 & 2,032 & $1,067,467$ \\
\hline Active population & 82,000 & 23,789 & 208,017 & 2,526 & $1,367,068$ \\
\hline Working age population & 180,138 & 52,284 & 428,575 & 10,672 & $2,812,315$ \\
\hline Total population & 296,136 & 96,763 & 689,109 & 18,022 & $4,546,343$ \\
\hline Public employment & 13,200 & 5,495 & 30,638 & 368 & 243,589 \\
\hline \multicolumn{6}{|c|}{ Employment and population levels in $2001(\mathrm{~N}=83)$} \\
\hline Tradable employment & 22,523 & 6,218 & 62,847 & 993 & 487,367 \\
\hline Non-tradable employment & 67,688 & 23,003 & 172,171 & 5,397 & $1,252,375$ \\
\hline Total employment & 119,700 & 43,641 & 294,959 & 10,447 & $2,033,004$ \\
\hline Active pop & 141,829 & 52,138 & 340,127 & 13,247 & $2,357,121$ \\
\hline Working a & 228,056 & 87,123 & 520,014 & 19,828 & $3,609,102$ \\
\hline Total pop & 330,320 & 126,410 & 747,146 & 31,158 & $5,135,225$ \\
\hline Public employment & 29,489 & 12,459 & 64,742 & 1,872 & 488,260 \\
\hline \multicolumn{6}{|c|}{$\begin{array}{l}\text { Employment and population decadal changes relative to the city's } \\
\text { population in the base year (1980-1990 \& 1990-2001 pooled changes, } N=166 \text { ) }\end{array}$} \\
\hline Tradable employment & 0.005 & 0.005 & 0.019 & -0.052 & 0.115 \\
\hline Non-trad & 0.061 & 0.052 & 0.041 & -0.067 & 0.264 \\
\hline Total emp & 0.095 & 0.089 & 0.058 & -0.137 & 0.308 \\
\hline Active pop & 0.109 & 0.103 & 0.060 & -0.119 & 0.356 \\
\hline Working age population & 0.109 & 0.090 & 0.091 & -0.029 & 0.584 \\
\hline Populatic & 0.105 & 0.078 & 0.160 & -0.088 & 0.959 \\
\hline Public employment & 0.029 & 0.028 & 0.019 & -0.031 & 0.093 \\
\hline \multicolumn{6}{|c|}{ Control variables: Pooled observations for 1980 and $1990(\mathrm{~N}=166)$} \\
\hline Unemployment rate & 0.181 & 0.170 & 0.061 & 0.042 & 0.406 \\
\hline Share of college graduates & 0.080 & 0.079 & 0.032 & 0.024 & 0.170 \\
\hline Coast & 0.446 & 0.000 & 0.499 & 0 & 1 \\
\hline Coast $n$ & 0.084 & 0.000 & 0.279 & 0 & 1 \\
\hline Share of vacation-homes & 18.684 & 11.603 & 16.252 & 3.830 & 77.826 \\
\hline Total population in 1970 & 240,644 & 75,857 & 566,044 & 12,776 & $3,630,338$ \\
\hline
\end{tabular}

Note: Variables as defined in the main text. 
of urban areas exceeds the national population growth for the period that we study (11.5 versus $8.6 \%)$.

\subsection{The geography of public sector employment expansion}

In Spain, the public sector developed late following Franco's death in 1975 and the introduction of the new constitution in 1978 . While in 1980 , the tax revenue to GDP ratio was only $22.6 \%$, by 2001 this ratio had reached $33.9 \%{ }^{22}$. This growth in the relative size of the public sector, combined with vigorous economic growth (the average annual real GDP growth rate between 1980 and 2001 was almost 3.0\%) resulted in very large increases in public sector jobs. Between 1980 and 2001, there were job increases of 139.5, 108.8 and $153.6 \%$ in public administration, education and health, respectively. Taking the three sectors together, the increase in the number of public sector jobs during this period amounts to $133.1 \%$, growing from 1.4 million in 1980 to almost 3.2 million jobs in $2001^{23}$.

In Spain, there are provincial and regional capitals. Provinces (and the associated capitals) were established in 1833 by Javier de Burgos and constituted the main territorial division of the country until the advent of democracy. Although the provinces were not suppressed, 17 regions (Comunidades Autï $\ddot{z}^{1 / 2}$ nomas) were built as aggregations of one or more provinces around 1981. Twenty years later, Spain was a decentralized country where regional governments employed $45 \%$ of public employees while the central and local governments employed the remaining 34 and $21 \%^{24}$.

The size of the public sector at the city level is determined by and large by its administrative status. Figure 2 plots the presence of public employees in cities, distinguishing between regional and provincial capitals, and non-capital cities. With two exceptions (Mï $i^{1 / 2}$ rida and Santiago de Compostela), the cities hosting regional governments are also provincial capitals ${ }^{25}$. Non-capital cities, such as El Ejido, Elda-Petrer and Torrevieja, have the lowest presence of public employees in 2001 with less than 5 employees per 100 inhabitants. At the other extreme of the scale, provincial capitals, such as Soria, Teruel, Ciudad-Real and Toledo, have more than 15 public employees per 100 inhabitants. More generally, this figure corroborates that being a capital is associated with public employees, and the difference is especially large for small cities. Holding population size constant, the presence of public employment is similar in provincial and regional capitals. This suggests that the process of regional decentralization that took place in Spain between 1981

\footnotetext{
${ }^{22}$ OECD Statistics.

${ }^{23}$ For the three sectors making up the public sector as defined herein, public administration increased from 0.526 to 1.261 million jobs, the education sector rose from 0.463 to 0.967 million while employment in the health sector went from 0.382 to 0.970 million.

${ }^{24}$ Registro Central de Personal, Ministerio de Hacienda y de Administraciones $\ddot{i}_{i}{ }^{1 / 2}$ blicas.

${ }^{25}$ These two cities are historically important. Mï $i \frac{1}{2}$ rida was the capital of the Roman Lusitania province and Santiago de Compostela is the destination of a major Catholic pilgrimage route. Moreover, these are the third cities in two bicephalic regions: Extremadura (Cï $i^{1 / 2}$ ceres and Badajoz) and Galicia (La Coruï $i^{1 / 2 a}$ and Vigo).
} 
and 2001 was not accompanied by a significant shift in public employment from provincial to regional capitals. On the contrary, pre-democratic provincial capitals kept their status quo in terms of public employment. On the one hand, provincial institutions (Diputaciones being the most prominent example) persisted into democratic Spain. On the other hand, provincial capitals managed to attract regional government public jobs. In light of this, we only consider two types of city: capitals (regardless of their being provincial or regional) and non-capitals. There are 52 capital cities (50 provincial capitals in addition to $\mathrm{Mi} i^{1 / 2}$ rida and Santiago de Compostela) and 31 non-capital cities. Figure 1 shows the capital cities (in red) and non-capital cities (in blue) within Spain.

Figure 2: Public sector employees in 2001 per 100 inhabitants

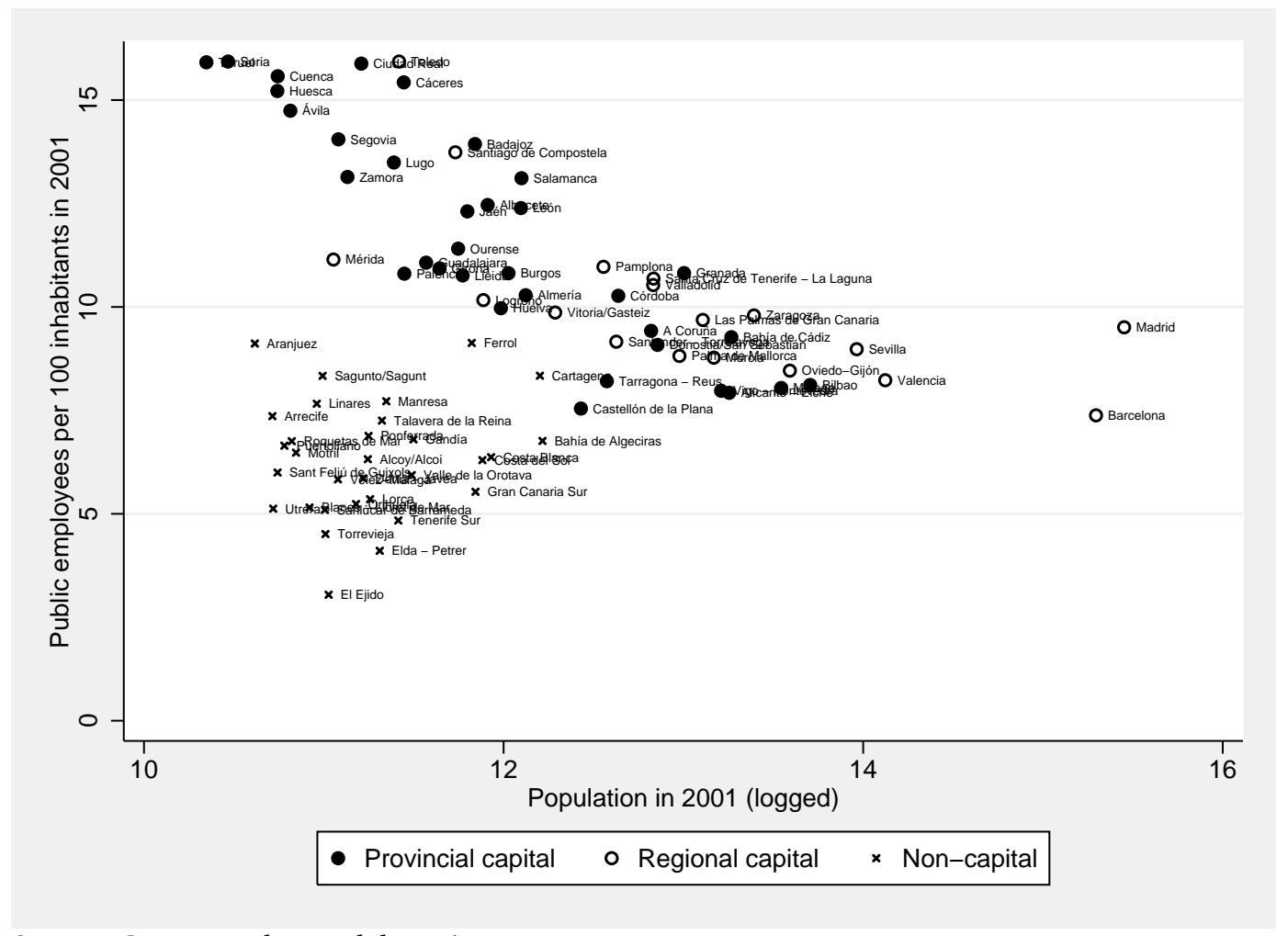

Source: Census and own elaboration.

Figure 3 plots the (per capita) increase in public sector employment between 1980 and 2001 in the capital and non-capital cities. It shows that when public sector employment grew after the advent of democracy, growth was more pronounced in the capital cities, the differences being especially notable in small cities. The first row in Table 6 quantifies the (raw) over-representation of public employment in the capital cities. While the non-capital cities had 6.3 public sector workers per 100 inhabitants in 2001, the corresponding figure for the capital cities was 11.1. Although the difference is smaller in magnitude, per capita public sector workers also increased more in the capital cities between 1981 and 2001. The increase was 3.6 in non-capital cities vs. 5.1 in capital cities. Rows 2 to 4 in Table 6 show that the over-representation of public employment in capital cities, both in 2001 levels as well as in the changes between 1980 and 2001, 
occurred in public administration but also in the education and health sectors, as institutions like universities and hospitals also tend to concentrate in capital cities.

Figure 3: Public sector job increase between 1980 and 2001 per 100 inhabitants

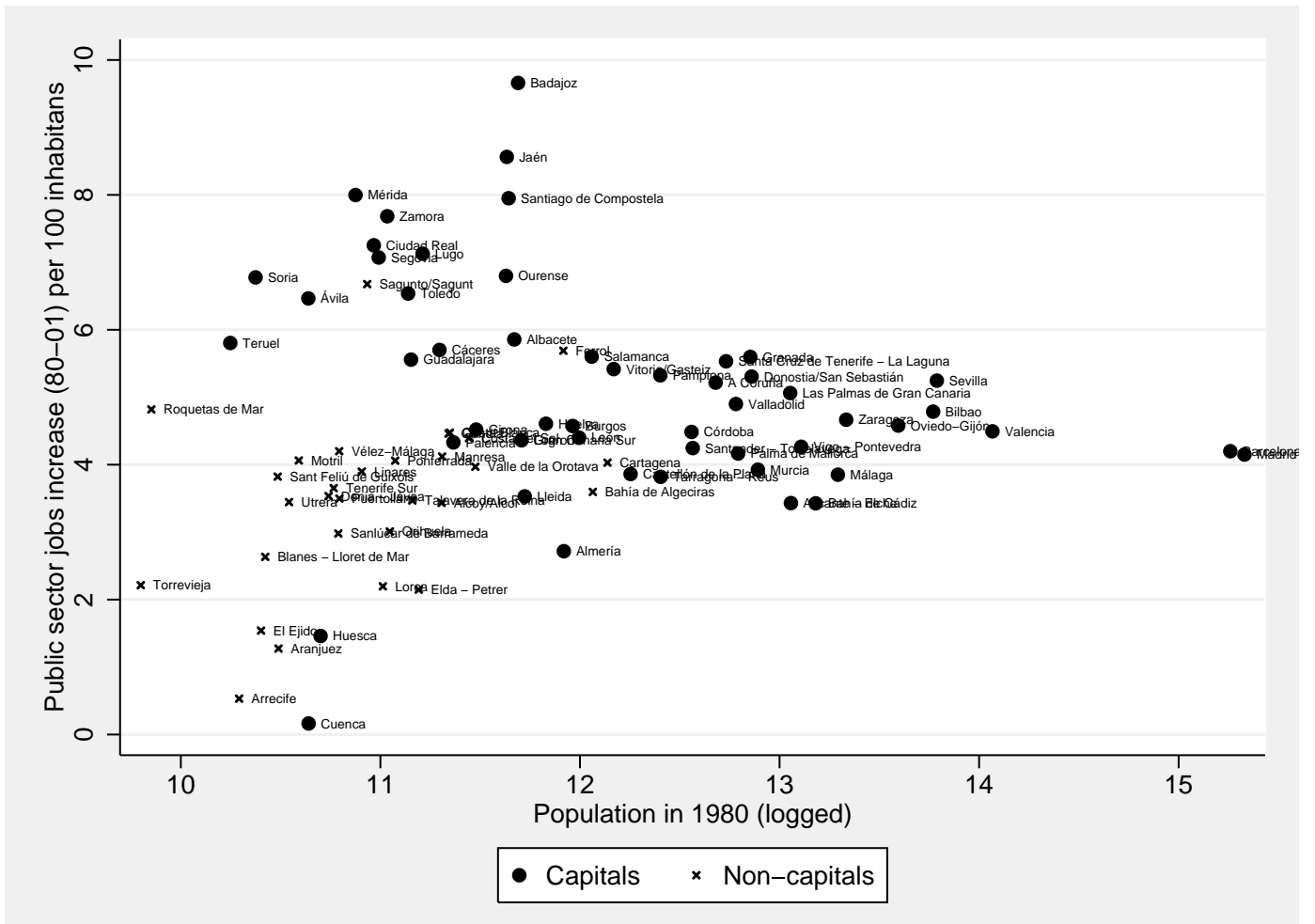

Source: Census and own elaboration.

We now turn to a more systematic analysis of the city-level determinants of the public sector employment expansion in the period 1980-2001. Specifically, we run regressions of the following type:

$$
\frac{E_{g, t+10}-E_{g, t}}{\text { Pop }_{t}}=\alpha_{t}+\beta \cdot \text { Capital }+\delta x+\epsilon_{t}
$$

where the left-hand side variable is the decadal increase in public sector jobs (1980-1990 or 1990-2001) relative to the total population level $\left(\right.$ Pop $\left._{t}\right)$ in the base year (1980 or 1990) ${ }^{26}$. In turn, $\alpha_{t}$ is a set of time dummies while Capital is an indicator variable for capital cities. Finally, $x$ contains some control variables that we consider in some of the specifications.

The first column of Table 7 shows the results with no other control variables than time dummies. These estimates indicate that, in the period 1980-2001, being a capital implied an additional 0.7 public workers each decade for every 100 inhabitants in the city in the base year. In the second column, we also consider population growth as a control variable despite its endogenous nature (public sector jobs might increase population as the model developed above

\footnotetext{
${ }^{26}$ This variable will become the main explanatory variable in the next section when we turn to the multiplier effects of public employment. Its summary statistics are provided in the third panel (last row) of Table 5.
} 
Table 6: Public sector jobs in capital versus non-capital cities (per 100 inhabitants)

\begin{tabular}{lcccc}
\hline \hline & \multicolumn{2}{c}{2001} & \multicolumn{2}{c}{$1980-2001$} \\
\hline Cublic sector & 11.120 & 6.320 & 5.140 & 3.550 \\
Public administration & 4.530 & 2.390 & 2.060 & 1.460 \\
Education & 3.170 & 1.950 & 1.510 & 0.850 \\
Health & 3.420 & 1.970 & 1.560 & 1.240 \\
\hline \hline
\end{tabular}

Note: Census and own elaboration.

predicts). When doing so, the capital effect increases, implying that being a capital is associated with 1.1 extra public jobs for every 100 inhabitants each decade. To assess the relative magnitude of this effect, note that the population growth coefficient (0.036) indicates that an increase of 100 residents is associated with an increase of 3.6 public sector workers. As explained above, there is ample evidence from different countries indicating public employment is used to offset local labor demand shocks. To test if this has also been the case in our application, in the last specification (column 3), we include a Bartik (1991) shift-share variable that captures demand driven private employment changes in city:

$$
\text { Bartik shift-share } \equiv \frac{\sum_{h}\left(\frac{E_{h, t}}{E_{h, t}^{\tilde{N}}}\right)\left(E_{h, t+10}^{\widetilde{N}}-E_{h, t}^{\widetilde{N}}\right)}{\operatorname{Pop}_{t}},
$$

where $E_{h, t}$ stands for city employment in the private (2-digit industry) $h$ in year $t$, while the superscript $\widetilde{N}$ denotes national employment levels. The predicted employment change in equation 18 captures the component of the 1980-1990 and 1990-2001 local employment shock explained by the city's industry mix in the base year (1980 or 1990) interacted with the decadal (1980-1990 or 1990-2001) fate of industries at the national level. The results indicate that for each job lost as a result of a demand shock in a city, the public sector has created 0.194 jobs in the public sector in that city. This provides direct evidence that public employment has been used as a prominent policy instrument to offset local economic shocks. Note that these policy responses are important since they would bias downwards the Ordinary Least Squares (OLS) estimates in the regressions (which we turn to next) that estimate the effect of public employment on local private employment. As for the capital variable, the results of this last specification are slightly higher, implying that capital cities gained 1.6 additional public sector jobs per decade for every 100 inhabitants in the period 1980-2001. 
Table 7: The determinants of public sector job increases

\begin{tabular}{lccc}
\hline \hline & $(1)$ & $(2)$ & $(3)$ \\
\hline & & & \\
Capital & $0.007^{* * *}$ & $0.011^{* * *}$ & $0.016^{* * *}$ \\
& $(0.002)$ & $(0.002)$ & $(0.003)$ \\
Population growth & & $0.036^{* * *}$ & $0.042^{* * *}$ \\
& & $(0.007)$ & $(0.008)$ \\
Bartik shift-share & & & $-0.194^{* * *}$ \\
& & & $(0.060)$ \\
\hline R-squared & 0.041 & 0.119 & 0.165 \\
Observations & 166 & 166 & 166 \\
\hline \hline
\end{tabular}

Notes: 1) 1980-1990 and 1990-2001 pooled observations 2) Robust standard errors clustered at the city-level in parentheses. 3) ${ }^{* * *}$ denotes statistical significance at the $1 \%$ level. 4) Population growth is the contemporaneous decadal population growth rate. 5) The Bartik shift-share is defined in equation 18.

\subsection{Public employment multipliers}

\subsubsection{Econometric specification}

We now turn to the estimation of public sector employment multipliers. Specifically, we estimate the impact of (decadal) changes in public employment on contemporaneous changes in measures of employment and population. All employment and population changes are divided by the city's total population level at the beginning of the decade. We run variants of the following specification.

$$
\frac{Y_{t+10}-Y_{t}}{\operatorname{Pop}_{t}}=\gamma \frac{E_{g, t+10}-E_{g, t}}{\operatorname{Pop}_{t}}+\eta x_{t}+\zeta_{t},
$$

where $Y$ stands for tradable, non-tradable and total employment, and active, working age, and total population $\left(\operatorname{Pop}_{t}\right)$. In addition to the change in public employment $\left(E_{g}\right)$, the specification includes a vector containing control variables $\left(x_{t}\right)$ and the error term $\left(\zeta_{t}\right)$.

As revealed by the analysis of the determinants of the expansion of the public sector in Table 7 , the public sector used its job openings to offset negative private employment shocks. These policy responses would tend to underestimate OLS estimates. On the other hand, we have seen that cities that grow more hire more public employees (probably) to provide public services to a larger population. Since growing cities are likely to create more private as well as public jobs, this would over-estimate the effect of public employment on private jobs. Hence, OLS estimates might be either under- or over-estimates of the effect of public sector expansions on private employment and population. 


\subsubsection{Capital cities as instrument}

To address these endogeneity concerns we adopt an instrumental variables' strategy. Concretely, we use the capital status of a city to instrument for changes in public employment relative to the population level in the base year ${ }^{27}$. For the instrumental variables' approach to work, the instrument needs to be both relevant and valid. In terms of relevance, the estimates in Table 7 indicate that, indeed, capital cities attracted more public sector jobs. According to the results in the last column, capital cities gained 0.016 additional public sector jobs per inhabitant in the base, per decade, in the period 1980-2001. Below, we formally test and reject the hypothesis that the instrument is weak. As explained above, provincial capitals were established in 1833 and, therefore, are clearly pre-determined with respect to our outcome variables. Hence, capital cities could have not been possibly picked based on economic performance when Comunidades Autónomas were created around 1981. Nevertheless, the instrument could be invalid if there are unobserved factors that are correlated both with capital status and with contemporaneous shocks in private employment or population. We address this identification threat by including a comprehensive set of time-invariant as well as time-varying controls.

Capital cities differ from non-capital cities in several ways besides public employment. First, capitals have a lower unemployment rate (the average unemployment rate -pooling 1981 and 1991 - is 16.9 and 20.0 for capital and non-capital cities) and a larger fraction of college graduates (the average share of college graduates -pooling 1981 and 1991- is 9.7 and 5.8 for capital and non-capital cities). As Figure 1 shows, capitals are also less likely to be on the Mediterranean and Canaries' coasts. Finally, capital cities are larger as can be readily seen in Figure 2. To control for all these (potential) confounders, all Two-Stage Least Squares (TSLS) estimations contain, in addition to time dummies, the unemployment rate and the share of college graduates measured at the beginning of the decade, the share of vacation homes in 1991 and two coastal indicators $^{28}$, NUTS1 dummies to capture regional specific trends in employment and population ${ }^{29}$, as well as a second order polynomial of the (logged) population level in 1970 to account for mean reversion in population growth.

\footnotetext{
${ }^{27} \mathrm{An}$ alternative instrument would consist in building a public employment shift-share variable, which is the approach taken by Faggio and Overman (2014). Specifically, public employment in the base year is used to predict subsequent employment growth based on the national growth rate of public employment. In our context, however, this instrument turns out to be weak as it is not a strong predictor of public employment changes in the subsequent decade.

${ }^{28}$ We include one for the North Atlantic coast (Mar Cant $i \ddot{z}^{1 / 2}$ brico) with less tourism and one for the coasts of the Mediterranean, the Andalusian Atlantic and the Canaries coasts.

${ }^{29}$ North west: Galicia, Asturias and Cantabria; North East: Basque Country, Navarre, La Rioja, Aragon; Madrid; Centre: Castile and Leon, Castile-la Mancha, Extremadura; East: Catalonia, Valencian Community and Balearic Islands; South: Andalusia, Region of Murcia; Canary Islands.
} 


\subsection{3 (Two-Stage Least Squares) main results}

The results are reported in Table 8 where each row shows the effect of a public sector job increase on a different outcome. The first column shows the results of specifications that include the controls described above. The results indicate that public sector jobs do not significantly increase nor decrease employment in the tradable sector. In contrast, the estimate in the second row indicates that one additional job in the public sector creates almost 1.4 jobs in the nontradable sector. The effect on total employment (row c) is about 2.8 which includes the public job being created and the additional positive effect on private employment. The effects on population are sizable, too. One job in the public sector increases the city's labor force by 3.2 workers (row d) and the working age population by 5.1 (row e). Finally, the coefficient on total population is 7.0, indicating that city size is very responsive to the creation of public sector jobs (row f). As explained above, instrument relevance can be tested formally. At the bottom of Table 8, we report the F-test of excluded instruments obtained in a regression where the standard errors are clustered at the city-level. The values of the F-test beyond indicate that, indeed, capital cities attracted more public sector jobs ${ }^{30}$.

The controls included in the first column of Table 8 can be seen as time invariant. It might also be the case that capital cities have experienced systematic employment or population shocks which could confound our estimates. To try to measure these shocks, in column 2 we also control for lagged population growth. To account for different industry specialization patterns between capital and non-capital cities, in column 3 we also add the Bartik shift-share employment change as defined in 18 to capture labor demand shocks ${ }^{31}$. Finally, in column 4 , we additionally include the lagged dependent variable (1970-1980 and 1980-1990 values for the 1980-1990 and 1990-2001 observations, respectively). Since data on the active and the working-age population for 1970 are not available, we cannot estimate this specification for rows d) and e). Including both the lagged population growth and the Bartik shift-share reduce the size of the estimated multipliers. Further including the lagged dependent variable does not reduce the size of the estimated multipliers. In light of these results, and given that we cannot estimate the multipliers for active and working age-population, we deem the estimates in column 3 as our baseline multipliers. One additional public employee leaves tradable employment largely unchanged (multiplier is 0.029 ), while it increases employment in the non-tradable industry by 0.866 workers. The estimated multiplier for total employment becomes 1.888 and considers the direct job created in the public sector. These additional jobs increase active, working-age and total population by 2.300, 2.829 and 3.733 individuals for each job in the public sector, respectively.

The estimated multipliers for the non-tradable sector and for the labor force are not too dif-

\footnotetext{
${ }^{30}$ The capital coefficient in the corresponding first-stage regression is 0.017 which is very close to 0.016 , the estimate obtained in the last specification of Table 7.

${ }^{31}$ In rows a) and b), $h$ includes tradable and non-tradable industries, respectively, while in rows c) to f), $h$ includes both tradable and non-tradable (private) industries.
} 
Table 8: Public employment multipliers: TSLS estimates

\begin{tabular}{lcccc}
\hline \hline & 1 & 2 & 3 & 4 \\
\hline a) Tradable employment & 0.364 & 0.322 & 0.029 & 0.059 \\
& $(0.337)$ & $(0.383)$ & $(0.289)$ & $(0.287)$ \\
b) Non-tradable employment & $1.404^{* * *}$ & $0.951^{* *}$ & $0.866^{* *}$ & $0.848^{* *}$ \\
& $(0.449)$ & $(0.437)$ & $(0.351)$ & $(0.367)$ \\
c) Total employment & $2.769^{* * *}$ & $2.273^{* * *}$ & $1.888^{* * *}$ & $1.946^{* * *}$ \\
& $(0.638)$ & $(0.647)$ & $(0.486)$ & $(0.460)$ \\
d) Active population & $3.156^{* * *}$ & $2.697^{* * *}$ & $2.300^{* * *}$ & \\
& $(0.713)$ & $(0.737)$ & $(0.560)$ & \\
e) Working-age population & $5.148^{* * *}$ & $3.701^{* * *}$ & $2.829^{* * *}$ & \\
& $(1.510)$ & $(1.311)$ & $(0.986)$ & \\
f) Total population & $7.037^{* * *}$ & $6.858^{* * *}$ & $3.733^{* *}$ & $3.733^{* *}$ \\
& $(2.196)$ & $(2.530)$ & $(1.728)$ & $(1.728)$ \\
\hline Unemployment rate & $\mathrm{Y}$ & $\mathrm{Y}$ & $\mathrm{Y}$ & $\mathrm{Y}$ \\
Share of college graduates & $\mathrm{Y}$ & $\mathrm{Y}$ & $\mathrm{Y}$ & $\mathrm{Y}$ \\
Coastal dummies & $\mathrm{Y}$ & $\mathrm{Y}$ & $\mathrm{Y}$ & $\mathrm{Y}$ \\
Share of vacation-homes in 1991 & $\mathrm{Y}$ & $\mathrm{Y}$ & $\mathrm{Y}$ & $\mathrm{Y}$ \\
Logged pop in 1970 (2nd order pol.) & $\mathrm{Y}$ & $\mathrm{Y}$ & $\mathrm{Y}$ & $\mathrm{Y}$ \\
NUTS 1 region dummies & $\mathrm{Y}$ & $\mathrm{Y}$ & $\mathrm{Y}$ & $\mathrm{Y}$ \\
Lagged pop growth & $\mathrm{N}$ & $\mathrm{Y}$ & $\mathrm{Y}$ & $\mathrm{Y}$ \\
Bartik shift-share & $\mathrm{N}$ & $\mathrm{N}$ & $\mathrm{Y}$ & $\mathrm{Y}$ \\
Lagged dependent variable & $\mathrm{N}$ & $\mathrm{N}$ & $\mathrm{N}$ & $\mathrm{Y}$ \\
F-test of excluded instruments & 15.010 & 11.250 & 17.170 & 22.300 \\
N & 166 & 166 & 166 & 166 \\
\hline \hline
\end{tabular}

Notes: 1) 1980-1990 and 1990-2001 pooled observations 2) Robust standard errors clustered at the city-level in parentheses. 3$)^{* * *}$,** and ${ }^{*}$ denote statistical significance at the 1,5 and $10 \%$ level. 4) Unemployment rate and share of college graduates measured at the beginning of the decade. 5) Coastal dummies include two dummies: One for the North Atlantic coast (Canti $i_{i}^{1} / 2 b r i c o$ ) and one for the coasts of the Mediterranean, the Atlantic in Andalusia and the Canaries coasts. 6) Regional fixed effects for the 7 NUTS1 Spanish regions. 7) The estimates for active population and working age population not shown in the specification with lagged dependent variables as these outcomes are not available for 1970. 8) As for the Bartik shift-share, in rows a) and b), $h$ includes tradable and non-tradable industries, respectively, while in rows c) to f), $h$ includes both tradable and nontradable (private) industries. 9) In columns 3 and 4, the F-statistic is not exactly the same for all outcomes as some controls differ (i.e. the Bartik shift-share and the lagged outcome). The reported statistics correspond to the total employment outcome but are virtually identical for the others.

ferent from those obtained when simulating the search and matching model in section 3: 0.866 versus 0.791 for the non-tradable sector and 2.3 versus 1.576 for the active population multiplier. In contrast, the results for the tradable sector are different. While the multiplier is -0.420 according to the simulated model, the corresponding TSLS (point) estimate is 0.029 . Although the manufacturing sector is a reasonable approximation to the tradable sector, in practice, parts of the manufacturing sector might sell a non-negligible share of their output to local customers. Examples of these industries include parts of the food, the publishing and printing, the furniture or the recycling industries. In these activities, a higher aggregate income at the city level might 
translate into higher local demand for these goods. This might partly explain this divergence in results. On top of this, note that the regression results indicate that public employment does not affect the absolute number of workers in the tradable sector despite causing large increases in population. As a result, the employment rate in the tradable sector (share of workers in the tradable sector) shrinks. Hence, the regression results also imply that cities in which public employment grew more did specialize less in the tradable sector.

Becker et al. (2018) find a negative multiplier of 0.19 for the tradable sector, and a positive multiplier of 1.05 for the non-tradable sector, implying that each public sector job increased private employment by 0.86. The multipliers in Faggio and Overman (2014) are lower. For a 4-year time horizon, they find a negative multiplier of 0.4 for the tradable sector and a positive multiplier of 0.5 for the non-tradable sector. When computed over a longer time horizon (8 years), the multiplier for the non-tradable sector becomes zero and the multiplier for the tradable sector becomes more negative, implying negative effects on private employment. In contrast to Becker et al. (2018) and our study, Faggio and Overman (2014) do not find that public employment causes increases in city size. As the authors recognize, the highly restrictive planning system prevalent in England (Hilber and Vermeulen, 2016) implies a very inelastic housing supply which might limit the population responses to a labor demand shock. Interestingly, the longrun results of Faggio and Overman (2014) resemble the simulation results that we find in the case of no mobility.

\subsubsection{Robustness checks}

In Section 4.2, we have documented that provincial capitals received more public sector jobs than other cities. Our findings could be misleading if other policy changes have affected capital versus non-capital cities differently. For our purposes, the two most problematic policies are the development and expansion of the motorway and university systems.

In the period 1980-2001, Spain developed a large motorway network that has been found to affect city growth (see, e.g. Garcia-López (2012) and Garcia-López et al. (2015)). Since the motorway network might have provided better connections to capital cities, in column 1 of Table 9 we add, as an additional control variable, the decadal contemporaneous increase in the number of motorway rays in the city ${ }^{32}$. The results indicate that the public employment multipliers that we estimate do not capture higher infrastructure investments in capital cities.

Particularly after the university reform in 1983, the Spanish university system expanded existing universities and created new institutions, especially in provincial capitals ${ }^{33}$. Although universities create public employment, they can affect a city's economy through different channels, including the accumulation of human capital. In order to assess if our results are driven

\footnotetext{
${ }^{32}$ Number of motorway rays in each city computed using the Mapa General de Carreteras - Ministerio de Fomento from the years 1980, 1990 and 2001.

${ }^{33}$ See Duch-Brown and García-Estévez (2011) for details on the expansion of the Spanish university system.
} 
by the growth of universities in provincial capitals, in column 2 we include, as a control variable, the decadal increase in university students measured relative to the population in the base year $^{34}$. Again, public employment multipliers do not change significatively, suggesting that our results are not driven by the expansion of the university system in capital cities.

As explained in Section 4.2, the advent of democracy in Spain came with a process of political decentralization with the creation of 17 regions (i.e. the so-called Comunidades Autónomas). As shown in Figure 2, cities do not have more public employees per capita if, in addition to being a provincial capital, they are also the capital of a Comunidad Autónoma. However, regional capitals concentrate more political power which could affect employment and population growth. For example, regional capitals might attract regulated industries, industries that regularly work for the government, or might be able to secure more public investments. To assess if our results are driven, not by public employment, but by other government activities that take place in cities, the estimates reported in the last column of Table 9 exclude regional capitals. The results support our previous findings, and suggest that our estimates are not driven by the higher political power of regional capitals.

We address other concerns regarding the robustness of our results in Appendix C. First, we check that the results are robust to excluding Barcelona and Madrid, the two largest cities in the country. We also show that the results are robust to excluding the smallest (below 35k) and the largest (above 202k) cities in our sample. Second, we report the results obtained using a narrower definition of the public sector. Specifically, we only consider public administration and exclude the health and education workers. Finally, for completeness, we also report OLS estimates corresponding to the baseline specifications.

\subsubsection{Do public sector jobs reduce local unemployment?}

The regression results obtained above clearly indicate that public sector jobs do increase private employment. However, they also show that population increases too and, thus, the effect on the unemployment rate is not obvious. To assess the implied effects on the unemployment rate of the estimates presented in Table 8, we take the average Spanish city in 2001 and assume that public employment increases by $50 \%$, which is the policy experiment that we have simulated with the calibrated model in section 3. The findings are reported in Table 10.

The second column of Table 10 reproduces the (baseline) estimated multipliers reported in

\footnotetext{
${ }^{34}$ For 1980 , we take the enrolled students by University in the academic year 1980-81 from the Anuario Estadistico de Espaï ${ }_{i}^{1} / 2$ a 1983. Since some Universities had schools in several cities, we sum students at the regional level (combining Madrid and Castilla la Mancha, and La Rioja and Aragón) and apportion students based on the distribution of university employees at the city level from the Censo de Locales de 1980. For the years 1991 and 2001 , we use the Census public use data files. For 2001, we can build university students by city of residence and by city of study. For University cities, the former is smaller than the latter, perhaps because of students reporting their parents' home as their place of residence. Hence, we take students by place of study. For 1991, only information on residence is available. To get a consistent time series, we multiply (resident) students in 1991 by the 2001 city-level ratio between university students studying in the city divided by university students living in that city.
} 
Table 9: Public employment multipliers: Other policies

\begin{tabular}{lccc}
\hline \hline & 1 & 2 & 3 \\
\hline a) Tradable employment & 0.002 & -0.006 & 0.161 \\
& $(0.284)$ & $(0.308)$ & $(0.287)$ \\
b) Non-tradable employment & $0.841^{* *}$ & $0.726^{* *}$ & $0.784^{* *}$ \\
& $(0.346)$ & $(0.357)$ & $(0.356)$ \\
c) Total employment & $1.853^{* * *}$ & $1.712^{* * *}$ & $2.033^{* * *}$ \\
& $(0.474)$ & $(0.495)$ & $(0.503)$ \\
d) Active population & $2.317^{* * *}$ & $2.035^{* * *}$ & $2.391^{* * *}$ \\
& $(0.549)$ & $(0.549)$ & $(0.616)$ \\
e) Working-age population & $2.768^{* * *}$ & $2.376^{* *}$ & $2.245^{* *}$ \\
& $(0.953)$ & $(0.962)$ & $(0.889)$ \\
f) Total population & $3.573^{* *}$ & $3.212^{*}$ & 2.145 \\
& $(1.708)$ & $(1.699)$ & $(1.642)$ \\
\hline Motorways & $\mathrm{Y}$ & $\mathrm{N}$ & $\mathrm{N}$ \\
University students & $\mathrm{N}$ & $\mathrm{Y}$ & $\mathrm{N}$ \\
Excluding regional capitals & $\mathrm{N}$ & $\mathrm{N}$ & $\mathrm{Y}$ \\
F-test of excluded instruments & 16.350 & 12.840 & 11.520 \\
$\mathrm{~N}$ & 166 & 166 & 130 \\
\hline \hline
\end{tabular}

Notes: 1) 1980-1990 and 1990-2001 pooled observations 2) Robust standard errors clustered at the city-level in parentheses. 3) ${ }^{* * *},{ }^{* *}$ and * denote statistical significance at the 1, 5 and $10 \%$ level. 4) All specifications include same controls as column 3 of Table 8. 5) Motorways is the decadal contemporaneous increase in the number of motorway rays. 6) University students is the decadal increase in students relative to the population in the base year. 7) Column 3 excludes capitals of Comunidades Autónomas. 8) In columns 3 and 4 , the F-statistic is not exactly the same for all outcomes as some controls differ. The reported statistics correspond to the total employment outcome but are virtually identical for the others.

column 3 of Table 8 . The new equilibrium is the result of adding to the 2001 mean, the respective multiplier times 14,745, which is a 50\% increase in public jobs for the average city in 2001 . Increasing public sector jobs by $50 \%$ increases tradable, non-tradable and total employment by $1.898,18.864$ and $23.256 \%$, respectively. At the same time, however, the active population grows at a very similar (and even higher) rate $(23.911 \%$ ) and the the unemployment rate slightly increases from 0.156 to 0.160 . As it turned out to be the case in the simulations of Section 3 , the additional jobs in the city do no reduce the unemployment rate because of the migration responses. As discussed above, an important trend in the Spanish labor market in the period studied was the marked increase in female labor force participation. Our estimates indicate that active population increases more than working-age population (23.911 vs $18.290 \%)$, resulting in an increase in the labor force participation rate from 0.622 to 0.651 . Despite this increase, note that migration seems to be the main margin through which local labor markets adjust to the increased number of jobs in the city. 
Table 10: Local labor market effects of public sector job expansions

\begin{tabular}{lcccc}
\hline \hline Variables & Mean 2001 & Multiplier & New Equilibrium & \% Change \\
\hline Tradable employment & 22,523 & 0.029 & 22,951 & 1.898 \\
Non-tradable employment & 67,688 & 0.866 & 80,457 & 18.864 \\
Total employment & 119,700 & 1.888 & 147,538 & 23.256 \\
Active population & 141,829 & 2.300 & 175,741 & 23.911 \\
Working age pop. & 228,056 & 2.829 & 269,768 & 18.290 \\
Population & 330,320 & 3.733 & 385,361 & 16.663 \\
Unemployment rate & 0.156 & & 0.160 & \\
Participation rate & 0.622 & & 0.651 & \\
\hline Public employment & 29,489 & & 44,234 & 50 \\
\hline \hline
\end{tabular}

Notes: 1) The new equilibrium is the result of adding to the 2001 mean, the respective multiplier times 14,745 (a $50 \%$ increase in public employment starting from 29,489 jobs).

\section{Summary and final remarks}

In this paper we have quantified the impact of public employment on Spanish local labor markets in the long-run by adopting two quantitative approaches. In the first one, we developed a 3-sector (public, tradable and non-tradable) search and matching model embedded within a spatial equilibrium model. We characterized the steady state of the model and calibrated it. We then used the model to simulate a policy consisting in expanding public sector employment in a city. In the second approach, we have used regression analysis to estimate the impact of public sector job growth on decadal changes (1980-1990 and 1990-2001) in the employment and population of Spanish cities. This analysis exploited the dramatic increase in public employment in the period 1980-2001, following Franco's death in 1975 and the advent of democracy in 1978. We resorted to an instrumental variables approach that used the capital status of cities to instrument for changes in public sector employment.

All in all, the empirical findings provided by the two empirical approaches indicate that public employment crowds-in private jobs in the city, with the additional jobs being concentrated in the non-tradable sector. The increase in jobs in the public and non-tradable sectors triggers migration responses and city size increases significantly. As a result, more jobs do not translate into a reduction of the local unemployment rate.

The model simulations indicate that the size of employment multipliers is determined by the size of migration responses. In that respect, the elasticity of land price with respect to city size and the income share spent on land are the two parameters to which the multipliers are more sensitive. Hence, more empirical research aimed at estimating these two parameters seems warranted. Finally, we note that we analyze the local labor market effects of public employment in a context where public employment is not funded locally. Hence, our results need not translate into instances in which public jobs are financed through local taxation.

An important message to be derived from this paper is that taking geographical mobility into 
account can be crucial for proper evaluation of the equity and efficiency of regional and local policies, as emphasized by Glaeser and Gottlieb (2008) when assessing the rationale for placebased initiatives. One caveat of this study is that the two quantitative analyses that we conduct are silent about the effects that creating public sector jobs in a given city has on the rest of the country. Specifically, a population inflow in one location is a population outflow somewhere else, implying that labor markets of origin locations are also affected by public employment. We leave these general equilibrium effects for future research.

\section{References}

Acemoglu, D. (2001). “Good Jobs versus Bad Jobs.” Journal of Labor Economics, 19(1), 1-21.

Albouy, D. (2009). “The Unequal Geographic Burden of Federal Taxation.” Journal of Political Economy, 117(4), 635-667.

Albrecht, J., Robayo-Abril, M., and Vroman, S. (2017). "Public Sector Employment in an Equilibrium Search and Matching Model.” The Economic Journal, forthcoming.

Alesina, A., Danninger, S., and Rostagno, M. (2001). "Redistribution Through Public Employment: The Case of Italy." IMF Staff Papers, 48(3), 2-44.

Algan, Y., Cahuc, P., and Zylberberg, A. (2002). "Public employment and labour market performance." Economic Policy, 17(34), 7-66.

Andersson, R. (2005). “The efficiency of Swedish regional policy.” The Annals of Regional Science, 39(4), 811-832.

Bartik, T. J. (1991). Who Benefits from State and Local Economic Development Policies? No. wbsle in Books from Upjohn Press, W.E. Upjohn Institute for Employment Research.

Beaudry, P., Green, D. A., and Sand, B. (2012). "Does Industrial Composition Matter for Wages? A Test of Search and Bargaining Theory.” Econometrica, 80(3), 1063-1104.

Beaudry, P., Green, D. A., and Sand, B. M. (2014). "Spatial equilibrium with unemployment and wage bargaining: Theory and estimation." Journal of Urban Economics, 79-Spatial Dimensions of Labor Markets, 2 - 19.

Becker, S. O., Heblich, S., and Sturm, D. M. (2018). “The Impact of Public Employment: Evidence from Bonn.” IZA Discussion Papers 11255, Institute for the Study of Labor (IZA).

Borge, L.-E., and Matsen, E. (2004). “Public Employment and Regional Risk Sharing.” Scandinavian Journal of Economics, 106(2), 215-230. 
Bover, O., and Arellano, M. (2002). "Learning about migration decisions from the migrants: Using complementary datasets to model intra-regional migrations in Spain." Journal of Population Economics, 15(2), 357-380.

Bover, O., and Velilla, P. (2005). "Migration in spain: Historical background and current trends.” In K. F. Zimmermann (Ed.), European migration: What do we know?, 389-414, Oxford University Press.

Bradley, J., Postel-Vinay, F., and Turon, H. (2017). "Public Sector Wage Policy and Labor Market Equilibrium: A Structural Model.” Journal of the European Economic Association, 15(6), 1214 1257.

Burdett, K. (2012). “Towards a theory of the labor market with a public sector.” Labour Economics, 19, 68-75.

Caponi, V. (2017). "Public employment policies and regional unemployment differences." Regional Science and Urban Economics, 63, 1 - 12.

Cardullo, G. (2017). “The Welfare and Employment Effects of Centralized Public Sector Wage Bargaining." Journal of Public Economic Theory, 19(2), 490-510.

Ciccone, A., and Hall, R. E. (1996). "Productivity and the Density of Economic Activity." American Economic Review, 86(1), 54-70.

Combes, P.-P., Duranton, G., and Gobillon, L. (2016a). “The Costs of Agglomeration: House and Land Prices in French Cities.” Mimeo, Wharton School, University of Pennsylvania.

Combes, P.-P., Duranton, G., and Gobillon, L. (2016b). “The production function for housing: Evidence from France.” Mimeo, Wharton School, University of Pennsylvania.

Combes, P.-P., and Gobillon, L. (2015). “Chapter 5 - the empirics of agglomeration economies.” In J. V. H. Gilles Duranton, and W. C. Strange (Eds.), Handbook of Regional and Urban Economics, Handbook of Regional and Urban Economics, vol. 5, 247 - 348, Elsevier.

Davis, M. A., and Ortalo-Magne, F. (2011). “Household Expenditures, Wages, Rents.” Review of Economic Dynamics, 14(2), 248-261.

de la Roca, J., and Puga, D. (2017). "Learning by working in big cities.” The Review of Economic Studies, 84(1), 106-142.

Duch-Brown, N., and García-Estévez, J. (2011). “Do universities affect firms’ location decisions? Evidence from Spain.” Working Papers 2011/7, Institut d' Economia de Barcelona (IEB). 
Faggio, G. (2015). “Relocation of public sector workers: Evaluating a place-based policy.” Discussion Paper 155, SERC/Urban and Spatial Programme Discussion Paper.

Faggio, G., and Overman, H. (2014). "The effect of public sector employment on local labour markets.” Journal of Urban Economics, 79-Spatial Dimensions of Labor Markets, 91-107.

Faggio, G., Schlüter, T., and vom Berge, P. (2018). "Interaction of public and private employment: Evidence from a german government move.” Discussion Paper 229, SERC/Urban and Spatial Programme Discussion Paper.

Garcia-López, M.-A. (2012). "Urban spatial structure, suburbanization and transportation in Barcelona." Journal of Urban Economics, 72(2), 176-190.

Garcia-López, M.-A., Holl, A., and Viladecans-Marsal, E. (2015). "Suburbanization and highways in Spain when the Romans and the Bourbons still shape its cities." Journal of Urban Economics, 85(C), 52-67.

Glaeser, E. L., and Gottlieb, J. D. (2008). “The Economics of Place-Making Policies.” Brookings Papers on Economic Activity, 39(1 (Spring), 155-253.

Gomes, P. (2015). “Optimal public sector wages.” The Economic Journal, 125(587), 1425-1451.

Gomes, P. (2018). "Heterogeneity and the public sector wage policy.” International Economic Review, forthcoming.

Hilber, C. A. L., and Vermeulen, W. (2016). "The impact of supply constraints on house prices in england.” The Economic Journal, 126(591), 358-405.

Hospido, L., and Moral-Benito, E. (2016). “The public sector wage premium in spain: Evidence from longitudinal administrative data.” Labour Economics, 42, 101 - 122.

Jofre-Monseny, J. (2014). "The effects of unemployment protection on migration in lagging regions." Journal of Urban Economics, 83, 73 - 86.

Kline, P., and Moretti, E. (2013). “Place Based Policies with Unemployment.” American Economic Review, 103(3), 238-43.

Kraus, F., Puhani, P. A., and Steiner, V. (1998). "Do public works programs work? Some unpleasant results from the East German experience.” Discussion Papers 98-07, ZEW-Centre for European Economic Research.

Marqués-Sevillano, J. M., and Rosselló-Villallonga, J. (2004). "Public employment and regional redistribution in spain." Hacienda Pública Española, 170(3), 59-80. 
Melo, P. C., Graham, D. J., and Noland, R. B. (2009). "A meta-analysis of estimates of urban agglomeration economies.” Regional Science and Urban Economics, 39(3), 332 - 342.

Moretti, E. (2010). “Local multipliers.” American Economic Review, 100, 373-377.

Moretti, E. (2012). The New Geography of Jobs. Houghton Mifflin Harcourt, New York.

Moretti, E., and Thulin, P. (2013). "Local multipliers and human capital in the united states and sweden." Industrial and Corporate Change, 22(1), 339-362.

OECD (2015). Government at a Glance 2015. OECD Publishing.

Pissarides, C. A. (2000). Equilibrium Unemployment Theory, 2nd Edition, MIT Press Books, vol. 1. The MIT Press.

Pissarides, C. A., and Petrongolo, B. (2001). "Looking into the Black Box: A Survey of the Matching Function." Journal of Economic Literature, 39(2), 390-431.

Roback, J. (1982). "Wages, rents, and the quality of life.” Journal of Political Economy, 90(6), $1257-1278$.

Rosenthal, S. S., and Strange, W. C. (2008). “The attenuation of human capital spillovers.” Journal of Urban Economics, 64(2), 373 - 389.

Shimer, R. (2005). “The Cyclical Behavior of Equilibrium Unemployment and Vacancies.” American Economic Review, 95(1), 25-49.

Silva, J. I., and Vázquez-Grenno, J. (2013). “The ins and outs of unemployment in a two-tier labor market." Labour Economics, 24(C), 161-169.

Wrede, M. (2015). "Wages, rents, unemployment, and the quality of life: A consistent theorybased measure." Journal of Regional Science, 55(4), 609-625.

\section{Appendix}

\section{A Wage equations}

In this appendix, we derive the wages in the tradable and non-tradable sectors with and without workers mobility. 


\section{A.1 Wage equations with labor mobility}

Starting with the wage maximization problem

$$
\max _{w_{i}}\left(W_{i}-U\right)^{\beta}\left(J_{i}-V_{i}\right)^{1-\beta}, \quad \text { with } i=t, n .
$$

and considering the free entry condition

$$
r V_{i}=0
$$

Then the FOC's

$$
\begin{gathered}
\beta\left(W_{i}-U\right)^{\beta-1} \frac{d W_{i}}{d w_{i}} J_{i}^{1-\beta}+\left(W_{i}-U\right)^{\beta}(1-\beta) \frac{d J_{i}}{d w_{i}} J_{i}^{-\beta}=0, \\
\beta\left(W_{i}-U\right)^{-1} \frac{d W_{i}}{d w_{i}} J_{i}=-(1-\beta) \frac{d J_{i}}{d w_{i}}, \\
\beta \frac{d W_{i}}{d w_{i}} J_{i}=-\left(W_{i}-U\right)(1-\beta) \frac{d J_{i}}{d w_{i}} .
\end{gathered}
$$

From equations 2, 3 and A-2:

$$
\begin{gathered}
J_{t}=\frac{A_{t}(L)-w_{t}}{r+s_{t}}, \\
J_{n}=\frac{p_{n} A_{n}-w_{n}}{r+s_{n}},
\end{gathered}
$$

then,

$$
\frac{d J_{i}}{d w_{i}}=\frac{-1}{r+s_{i}}
$$

Subtracting $r U$ from both sides of equation 8

$$
r\left(W_{i}-U\right)=\frac{w_{i}}{P}+s_{i}\left(U-W_{i}\right)-r U,
$$


operating,

$$
\left(W_{i}-U\right)=\frac{\frac{w_{i}}{P}-r U}{r+s_{i}}
$$

then,

$$
\frac{d W_{i}}{d w_{i}}=\frac{\frac{1}{P}}{r+s_{i}} .
$$

Substituting equation A-8 and A-10 in A-5 we obtain,

$$
\frac{1}{P} \beta J_{i}=(1-\beta)\left(W_{i}-U\right)
$$

Now, to obtain the wage equations 10 and 11 we start using condition A-12. Next, we solve for $J_{t}$ in 2 and $J_{n}$ in 3

$$
\begin{gathered}
J_{t}=\frac{A_{t}(L)-w_{t}}{\left(r+s_{t}\right)}, \\
J_{n}=\frac{p_{n} A_{n}-w_{n t}}{\left(r+s_{n}\right)} .
\end{gathered}
$$

Notice that the job creation conditions 4 and 5 are obtained by using A-13, A-14, 1 and the free entry condition A-2. Then, we solve for $W_{i}-U$ using 7 and 8 ,

$$
\left(W_{i}-U\right)=\frac{\frac{w_{i}}{P}-r U}{\left(r+s_{i}\right)}
$$

Now substitute A-13, A-14 and A-15 in A-12 and solve for $w_{i}$

$$
\begin{aligned}
& w_{t}=\left(\frac{\beta A_{t}(L)}{P}+(1-\beta) r U\right) P, \\
& w_{n}=\left(\frac{\beta p_{n} A_{n}}{P}+(1-\beta) r U\right) P .
\end{aligned}
$$


Finally, substituting $r U=z$ in equations A-16 and A-17 we obtain the wage equations 10 and 11.

\section{A.2 Wage equations without labor mobility}

To derive the wage equations in a without mobility context, we first have to obtain $r U$. For this, we use equations 7, 4 and 5 and substitute $J_{i}=\frac{k_{i}}{q(\theta)}$ in A-12,

$$
\left(W_{i}-U\right)=\frac{\beta}{(1-\beta)} \frac{k_{i}}{q(\theta) P},
$$

Next, we obtain $W_{g}-U$ using 7 and 8

$$
\left(W_{g}-U\right)=\frac{\frac{\left(w_{g}-b\right)}{P}-f_{t}\left(W_{t}-U\right)-f_{n}\left(W_{n}-U\right)}{\left(r+s_{g}+f_{g}\right)}
$$

Knowing that $\frac{f}{q(\theta)}=\theta$, we substitute A-18 and A-19 in 7 and obtain

$$
r U=\frac{1}{P}\left[b+f_{g}\left[\frac{\left(w_{g}-b-\frac{\beta \theta}{(1-\beta)}\left(\Omega_{t} k_{t}+\Omega_{n} k_{n}\right)\right)}{\left(r+s_{g}+f_{g}\right)}\right]+\frac{\beta \theta}{(1-\beta)}\left(\Omega_{t} k_{t}+\Omega_{n} k_{n}\right)\right] .
$$

Finally, by substituting A-20 into A-16 and A-17 we obtain the wage equations A-21 and A$22 .{ }^{35}$

$$
\begin{gathered}
w_{t}=\beta A_{t}(L)+\left((1-\beta) b+\beta \theta\left(\Omega_{t} k_{t}+\Omega_{n} k_{n}\right)\right) \frac{\left(r+s_{g}\right)}{\left(r+s_{g}+f_{g}\right)}+\frac{f_{g}(1-\beta) w_{g}}{\left(r+s_{g}+f_{g}\right)} \\
w_{n}=\beta p_{n}+\left((1-\beta) b+\beta \theta\left(\Omega_{t} k_{t}+\Omega_{n} k_{n}\right)\right) \frac{\left(r+s_{g}\right)}{\left(r+s_{g}+f_{g}\right)}+\frac{f_{g}(1-\beta) w_{g}}{\left(r+s_{g}+f_{g}\right)}
\end{gathered}
$$

\footnotetext{
${ }^{35}$ If there is no public employment $\left(f_{g}=s_{g}=0\right)$, the wage equations reduce to their standard form (Pissarides (2000), p.18). Specifically, $w_{t}=\beta A_{t}(L)+(1-\beta) b+\beta \theta\left(\Omega_{t} k_{t}+\Omega_{n} k_{n}\right)$ and $w_{n}=\beta p_{n}+(1-\beta) b+\beta \theta\left(\Omega_{t} k_{t}+\Omega_{n} k_{n}\right)$.
} 


\section{B The model equilibrium conditions}

In this appendix we derive the equilibrium equations of the model presented in section 2 . The following twenty-one equations characterize the behavior of the endogenous variables our model $\left(\theta, f_{g}, f_{t}, f_{n}, q(\theta), \Omega_{g}, \Omega_{t}, \Omega_{n}, v_{g}, v_{t}, v_{n}, p_{n}, p_{c}, w_{t}, w_{n}, e_{t}, e_{n}, L, A_{t}, P\right.$ and $\left.u\right):$

$$
\begin{aligned}
& \frac{k_{t}}{q(\theta)}=\frac{A_{t}(L)-w_{t}}{\left(r+s_{t}\right)}, \\
& \frac{k_{n}}{q(\theta)}=\frac{p_{n}-w_{n}}{\left(r+s_{n}\right)} \\
& u=\frac{s_{g} s_{t} s_{n}}{\left[s_{t} s_{n} s_{g}+s_{g} s_{t} f_{n}+s_{g} f_{t} s_{n}+f_{g} s_{t} s_{n}\right]}, \\
& e_{g}=\frac{f_{g}}{s_{g}} u \\
& e_{t}=\frac{f_{t}}{s_{t}} u \text {, } \\
& e_{g}+e_{t}+e_{n}+u=1 \text {, } \\
& f_{i}=f(\theta) \Omega_{i}, \forall i \\
& \Omega_{i}=\frac{v_{i}}{v}, \forall i \\
& f(\theta)=f_{g}+f_{t}+f_{n}, \\
& q(\theta)=\frac{f(\theta)}{\theta} \\
& \theta=\frac{v}{u}, \text { and } \\
& v=v_{t}+v_{n}+v_{g}, \\
& r U=\frac{b}{P}+f_{g}\left(\frac{\frac{w_{g}}{P}-z}{r+s_{g}}\right)+f_{t}\left(\frac{\frac{w_{t}}{P}-z}{r+s_{t}}\right)+f_{n}\left(\frac{\frac{w_{n}}{P}-z}{r+s_{n}}\right)=z,
\end{aligned}
$$




$$
\begin{gathered}
\phi\left(w_{g} e_{g}+w_{t} e_{t}+w_{n} e_{n}+b u\right)=p_{n} e_{n}, \\
p_{c}=L^{\eta}, \\
A_{t}(L)=A_{t_{0}} L^{\zeta}, \\
P=\left(\frac{1}{1-\phi-\delta}\right)^{(1-\phi-\delta)}\left(\frac{p_{n}}{\phi}\right)^{\phi}\left(\frac{p_{c}}{\delta}\right)^{\delta} .
\end{gathered}
$$

\section{Further regressions}

In this Appendix we conduct robustness checks that indicate that our results: 1) are robust to changes in the sample of cities, and 2) are robust to using a more restrictive definition of public sector by excluding the health and education sectors. Finally, we report the OLS estimates of the baseline specifications of Table 8 .

Note that our sample is limited in size (i.e. 83) as there is a limited number of urban areas in Spain. Besides, 1) there are more treated cities (capitals) than controls (non-capitals), and 2) capital cities are larger as Figure 2 shows. The results reported in Table A1 show that the results hold when alternative samples are specified, reducing the risk that our findings are driven by the presence of outliers or by an excessive dissimilarity between treated and control cities.

In column 1 of Table A1, we exclude the two main Spanish cities (Barcelona and Madrid) from the sample. Our sample consists of aggregations of municipalities that qualified as an urban area in 2008. However, some of these aggregations were not urban areas in 1980 but have experienced an intense growth process in the period we study. In column 2, we restrict the sample to the (76) urban areas whose population has remained above 35k inhabitants throughout the 1980-2001 period, with 35k inhabitants being the smallest urban area in 2001. Finally, in column 3, we exclude all cities with population exceeding $202 \mathrm{k}$ inhabitants at any point in the 1980-2001 period, with 202k inhabitants being the largest non-capital city in 2001. Overall, the results are robust to using alternative samples.

As explained in Section 4.1, the public sector definition used throughout the paper includes public administration, education and health. Given that the majority but not all employees in the education and health sectors are public employees, in Table A2 we report the TSLS estimates that we obtain when the employment changes in public employment only measures changes in jobs in the public adminstration sector ${ }^{36}$.

\footnotetext{
${ }^{36}$ In Table 8, the coefficient of total employment amounted to the sum of the tradable and non-tradable coef-
} 
Table A1: Public employment multipliers: TSLS estimates with alternative samples of cities

\begin{tabular}{lccc}
\hline \hline & 1 & 2 & 3 \\
& w/o Bcn \& Mad & $>35 \mathrm{k}$ & $<202 \mathrm{k}$ \\
\hline a) Tradable employment & 0.017 & -0.092 & -0.077 \\
& $(0.278)$ & $(0.277)$ & $(0.220)$ \\
b) Non-tradable employment & $0.782^{* *}$ & $0.702^{* *}$ & $0.724^{* * *}$ \\
& $(0.311)$ & $(0.281)$ & $(0.267)$ \\
c) Total employment & $1.784^{* * *}$ & $1.527^{* * *}$ & $1.643^{* * *}$ \\
& $(0.438)$ & $(0.402)$ & $(0.388)$ \\
d) Active population & $2.145^{* * *}$ & $1.958^{* * *}$ & $2.038^{* * *}$ \\
& $(0.489)$ & $(0.457)$ & $(0.457)$ \\
e) Working-age population & $2.224^{* * *}$ & $2.175^{* * *}$ & $1.933^{* * *}$ \\
& $(0.790)$ & $(0.622)$ & $(0.663)$ \\
f) Total population & $2.657^{*}$ & $2.289^{*}$ & $2.772^{* *}$ \\
& $(1.425)$ & $(1.346)$ & $(1.271)$ \\
\hline F-test of excluded instruments & 19.280 & 13.090 & 22.840 \\
$\mathrm{~N}$ & 162 & 152 & 116 \\
\hline \hline
\end{tabular}

Notes: 1) 1980-1990 and 1990-2001 pooled observations 2) Robust standard errors clustered at the city-level in parentheses. 3 ) ${ }^{* * * * *}$ and ${ }^{*}$ denote statistical significance at the 1,5 and $10 \%$ level. 4) All specifications include same controls as column 3 of Table 8. 5) Column 1 excludes Barcelona and Madrid. Column 2 excludes all cities with population below $35 \mathrm{k}$ thousand inhabitants in 1980. Column 3 excludes all cities with population that have exceeded 202k inhabitants in the 1980-2001 period. 6) The F-statistic is not exactly the same for all outcomes as some controls differ. The reported statistics correspond to the total employment outcome.

Although the F-tests of excluded instruments are a bit lower than those obtained in the exercise in which we consider a broad definition of public employment (public administration together with the health and education sectors), the instrument does not become weak. The estimated multipliers are qualitatively similar and statistically not different from those of Table 8 . Nevertheless, the point estimates are larger. One explanation for this is that, as shown in Table 6 , capital cities experienced larger job increases in public administration, health and education sectors. Hence, public administration multipliers might be over-estimated as they are likely to capture the private employment effects of health and education jobs.

Finally, for completeness, we report the Ordinary Least Squares (OLS) estimates of the baseline specifications of Table 8 in columns 2 to 5 in Table A3, while column 1 reports raw correlations from regressions that only contain time dummies as controls. As for non-tradable and total employment, TSLS and OLS estimates are reasonably similar. Instead, OLS estimates are smaller than the TSLS counterparts for population multipliers. The opposite is true for the tradable multiplier, where the OLS estimate is positive and statistically significant.

ficients plus one (the mechanical effect of public employment to total employment). This is no longer true in this exercise since we do not include the health and education sectors in the non-tradable sector. 
Table A2: Public administration multipliers: TSLS estimates

\begin{tabular}{lcccc}
\hline \hline & 1 & 2 & 3 & 4 \\
\hline a) Tradable employment & 0.540 & 0.476 & 0.044 & 0.089 \\
b) Non-tradable employment & $(0.498)$ & $(0.564)$ & $(0.437)$ & $(0.431)$ \\
& $2.082^{* * *}$ & $1.408^{*}$ & $1.231^{* *}$ & $1.197^{* *}$ \\
c) Total employment & $(0.786)$ & $(0.725)$ & $(0.553)$ & $(0.575)$ \\
& $4.104^{* * *}$ & $3.363^{* * *}$ & $2.767^{* * *}$ & $2.887^{* * *}$ \\
d) Active population & $(1.157)$ & $(1.121)$ & $(0.814)$ & $(0.792)$ \\
& $4.679^{* * *}$ & $3.990^{* * *}$ & $3.371^{* * *}$ & \\
e) Working-age population & $(1.317)$ & $(1.312)$ & $(0.973)$ & \\
& $7.631^{* * *}$ & $5.475^{* *}$ & $4.146^{* *}$ & \\
f) Total population & $(2.617)$ & $(2.150)$ & $(1.633)$ & \\
& $10.432^{* * *}$ & $10.148^{* *}$ & $5.470^{* *}$ & $5.470^{* *}$ \\
& $(3.784)$ & $(4.223)$ & $(2.754)$ & $(2.754)$ \\
\hline Unemployment rate & $\mathrm{Y}$ & $\mathrm{Y}$ & $\mathrm{Y}$ & $\mathrm{Y}$ \\
Share of college graduates & $\mathrm{Y}$ & $\mathrm{Y}$ & $\mathrm{Y}$ & $\mathrm{Y}$ \\
Coastal dummies & $\mathrm{Y}$ & $\mathrm{Y}$ & $\mathrm{Y}$ & $\mathrm{Y}$ \\
Share of vacation-homes in 1991 & $\mathrm{Y}$ & $\mathrm{Y}$ & $\mathrm{Y}$ & $\mathrm{Y}$ \\
Logged pop in 1970 (2nd order pol.) & $\mathrm{Y}$ & $\mathrm{Y}$ & $\mathrm{Y}$ & $\mathrm{Y}$ \\
NUTS 1 region dummies & $\mathrm{Y}$ & $\mathrm{Y}$ & $\mathrm{Y}$ & $\mathrm{Y}$ \\
Lagged pop growth & $\mathrm{N}$ & $\mathrm{Y}$ & $\mathrm{Y}$ & $\mathrm{Y}$ \\
Bartik shift-share & $\mathrm{N}$ & $\mathrm{N}$ & $\mathrm{Y}$ & $\mathrm{Y}$ \\
Lagged dependent variable & $\mathrm{N}$ & $\mathrm{N}$ & $\mathrm{N}$ & $\mathrm{Y}$ \\
F-test of excluded instruments & 12.880 & 9.840 & 13.910 & 17.990 \\
N & 166 & 166 & 166 & 166 \\
\hline \hline
\end{tabular}

Notes: 1) 1980-1990 and 1990-2001 pooled observations 2) Robust standard errors clustered at the city-level in parentheses. 3) ${ }^{* * *}, * *$ and ${ }^{*}$ denote statistical significance at the 1,5 and $10 \%$ level. 4) Controls as defined in Table 8. 5) In columns 3 and 4, the F-statistic is not exactly the same for all outcomes as some controls differ. The reported statistics correspond to the total employment outcome. 
Table A3: Public employment multipliers: OLS estimates

\begin{tabular}{lccccc}
\hline \hline Outcomes: & 1 & 2 & 3 & 4 & 5 \\
\hline a) Tradable employment & 0.087 & $0.120^{* *}$ & $0.115^{*}$ & $0.160^{* * *}$ & $0.156^{* * *}$ \\
b) Non-tradable employment & $(0.073)$ & $(0.060)$ & $(0.060)$ & $(0.045)$ & $(0.043)$ \\
& $0.545^{* * *}$ & $0.612^{* * *}$ & $0.575^{* * *}$ & $0.578^{* * *}$ & $0.557^{* * *}$ \\
c) Total employment & $(0.156)$ & $(0.140)$ & $(0.135)$ & $(0.135)$ & $(0.127)$ \\
& $1.632^{* * *}$ & $1.732^{* * *}$ & $1.690^{* * *}$ & $1.720^{* * *}$ & $1.647^{* * *}$ \\
d) Active population & $(0.183)$ & $(0.167)$ & $(0.161)$ & $(0.163)$ & $(0.137)$ \\
& $1.780^{* * *}$ & $1.839^{* * *}$ & $1.797^{* * *}$ & $1.825^{* * *}$ & \\
e) Working-age population & $(0.211)$ & $(0.176)$ & $(0.173)$ & $(0.176)$ & \\
& $0.938^{* *}$ & $0.749^{* * *}$ & $0.612^{* * *}$ & $0.661^{* * *}$ & \\
f) Total population & $(0.438)$ & $(0.288)$ & $(0.225)$ & $(0.231)$ & \\
& $1.679^{* * *}$ & $1.298^{* * *}$ & $1.231^{* *}$ & $1.466^{* * *}$ & $1.466^{* * *}$ \\
& $(0.573)$ & $(0.451)$ & $(0.500)$ & $(0.529)$ & $(0.529)$ \\
\hline Unemployment rate & $\mathrm{N}$ & $\mathrm{Y}$ & $\mathrm{Y}$ & $\mathrm{Y}$ & $\mathrm{Y}$ \\
Share of college graduates & $\mathrm{N}$ & $\mathrm{Y}$ & $\mathrm{Y}$ & $\mathrm{Y}$ & $\mathrm{Y}$ \\
Coastal dummies & $\mathrm{N}$ & $\mathrm{Y}$ & $\mathrm{Y}$ & $\mathrm{Y}$ & $\mathrm{Y}$ \\
Share of vacation-homes in 1991 & $\mathrm{N}$ & $\mathrm{Y}$ & $\mathrm{Y}$ & $\mathrm{Y}$ & $\mathrm{Y}$ \\
Logged pop in 1970 (2nd order pol.) & $\mathrm{N}$ & $\mathrm{Y}$ & $\mathrm{Y}$ & $\mathrm{Y}$ & $\mathrm{Y}$ \\
NUTS 1 region dummies & $\mathrm{N}$ & $\mathrm{Y}$ & $\mathrm{Y}$ & $\mathrm{Y}$ & $\mathrm{Y}$ \\
Lagged pop growth & $\mathrm{N}$ & $\mathrm{N}$ & $\mathrm{Y}$ & $\mathrm{Y}$ & $\mathrm{Y}$ \\
Bartik shift-share & $\mathrm{N}$ & $\mathrm{N}$ & $\mathrm{N}$ & $\mathrm{Y}$ & $\mathrm{Y}$ \\
Lagged dependent variable & $\mathrm{N}$ & $\mathrm{N}$ & $\mathrm{N}$ & $\mathrm{N}$ & $\mathrm{Y}$ \\
N & 166 & 166 & 166 & 166 & 166 \\
\hline
\end{tabular}

Notes: 1) 1980-1990 and 1990-2001 pooled observations 2) Robust standard errors clustered at the city-level in parentheses. 3) ${ }^{* * *},{ }^{* *}$ and ${ }^{*}$ denote statistical significance at the 1,5 and $10 \%$ level. 4) Controls variables in columns 2 to 5 are the same as those included in columns 1 to 4 of Table 8, while in column 1 only time dummies are accounted for. 